\title{
CAN INDUSTRIALIZATION AFFECT HEAVY METALS BIOCONCENTRATION IN DATE PALM TREE FARMS IN THE SULTANATE OF OMAN?
}
M.A. M. Al-Shali ${ }^{1,2 *}$
A. Kalyani ${ }^{1}$
A.I.Ndaginna ${ }^{3}$
K. Yardi ${ }^{1}$,

${ }^{1}$ Instit. of Environ. Educat. and Resear., Bharati Vidyapeeth Univ. , Katraj, Dhankawadi,

Pune, 411043, India

2. Min. of Agric. and Fisheries, Muscat, Sultanate of Oman.

${ }^{3}$ School of Environ.Natural Res. and Geog. Bangor Univ., Deiniol Road, Bangor, LL57 2UW,

UK

*Corresponding Author: future.mo557@gmail.com

\section{ABSTRACT}

Purpose Industrialization is leading to gradual accumulation of heavy metals in the date palm fruits and ecosystem. This paper aims at estimating the bioaccumulation of heavy metals in soils, fruits (dates) near the industrial area of Al-Rusail in the Sultanate of Oman. There were three sites located for sampling and each with three farms except site 3 with one farm; industrial site, cement factory and control farm. The soil, water and date palm fruits were analyzed for heavy metals concentration using inductively coupled plasma optical emission spectrometer. The results of analysis showed that the mean concentration of heavy metals in soil was in the following order: $\mathrm{Ni}>\mathrm{Zn}>\mathrm{Pb}>\mathrm{Cd}$. The concentration of heavy metals in the groundwater was found to be in this order $\mathrm{Zn}>\mathrm{Ni}>\mathrm{Pb}>\mathrm{Cd}$, and $\mathrm{Zn}>\mathrm{Pb}>\mathrm{Ni}>\mathrm{Cd}$ in fruits. The statistical interaction of heavy metal mean concentrations indicated cadmium with the highest mean $(0.007117 \mathrm{mg} / \mathrm{kg})$ in Farm 1 during the month of June at $0-30 \mathrm{~cm}$ $(\mathrm{mg} / \mathrm{kg})$ in soil under Industrial sites. The fruit stages differ statistically with the highest concentration of zinc ranging from $0.190517 \mathrm{mg} / \mathrm{Kg}$ of khalal stage of farm 1 to the $0.03127 \mathrm{mg} / \mathrm{kg}$ of the control farm. groundwater heavy metal concentration was very low across the farms with the least (Cd at $0.0002434 \mathrm{mg} / \mathrm{Kg}$ ) in control site and not statistically different from other sites' farms.In general, the research indicated an increases in the heavy metal concentrations with closeness to industrial sites.

Keywords bioconcentration,date-palm, farmlands,heavy Metals, Pollution, cement , plasma,

الثالي وآخرون

مجلة العلوم الزراعية العراقية -172-152:50:2019) مداصد خاص)

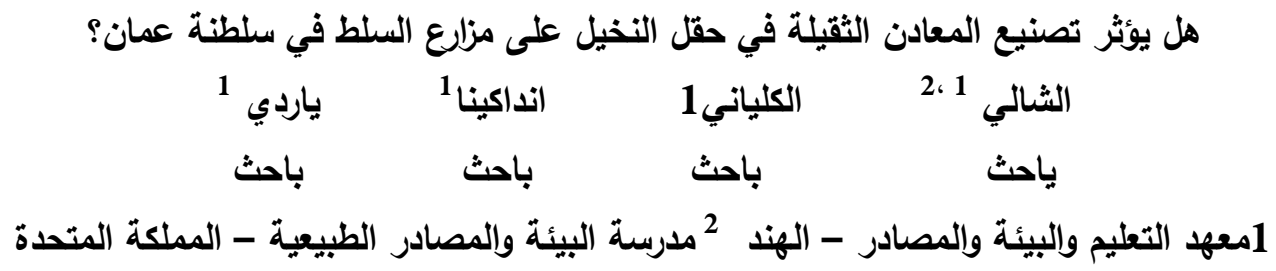

المستخلص

يؤدي التصنيع إلى تراكم تدريجي للمعادن الثقيلة في فاكهة النخيل و المنظومة البيئية . تهدف هذه الدراسة إلى تقدير التراكم الأحيائي للمعادن الثقيلة في التربة والفاكهة (التمور) بالقرب من منطقة الرسيل الصناعية في سلطنة عمان. اخذت ثثلاثة عينات من مواقع مختلفة وكل منها بثلاث مزارع عدا الموقع 3 من مزرعة واحدة ؛ الموقع الصناعي ومصنع الاسمنت ومزرعة التحكم. تم تحليل ثمار التربة والمياه

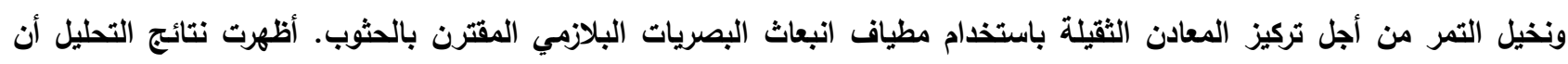
متوسط تركيز المعادن الثقيلة في التربة كان بالترتيب التالي: Ni> Zn> Pb> Cd. تم العثور على تركيز المعادن الثقيلة في المياه الجوفية في هذا الترتيب Zn> Pb> Ni> Cd و Z Zn> Ni> Pb> Cd في الفواكه. أظهر التفاعل الإحصائي لتركيزات متوسطات

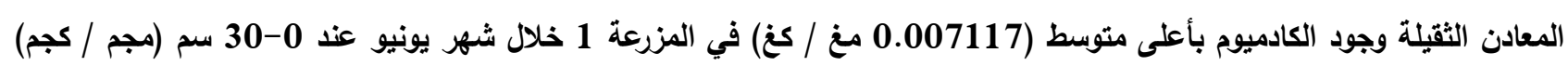
في التربة تحت المواقع الصناعية. تختلف مراحل الثمار إحصائياً مع أعلى تركيز للزنك يتراوح من فئل

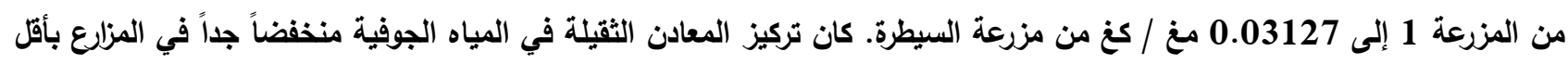

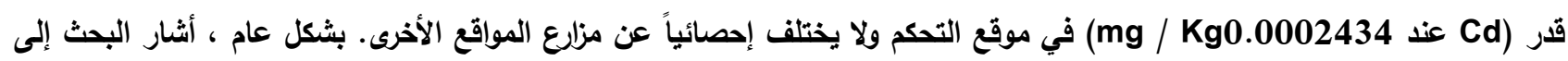
زيادة في تركيزات المعادن الثقيلة مع القرب من مواقع صناعية. كلمات مفتاحية: تلوت البيئي، كاديوم، رصاص، زنتك، تلوث 


\section{INTRODUCTION}

Date palm tree (Phoenix dactylifera L.) is perennial, dioecious, monocot tree that is widely grown in arid and semi-arid regions. It is heterozygous in nature and widely distributed in Oman, except in Dhofar governorate where the wet monsoon climate supports soil moisture all year round. Date palm trees require hot climate and dry weather in the regions where they are found. There are 250 indigenous cultivars of date palm in Oman (14). Dates have antioxidant activity due to the presence of flavonoids in date palm fruits. In recent times, Kuwait, Saudi Arabia, Jordan and Turkey have considered date palm trees as biomonitors for pollutant research $(15,43$ ).Heavy metals as bioaccumulators are biologically poisonous if allowed to increase beyond threshold level. The accumulation levels in soil and sediments are highly concentrated and readily taken up by plants during growth $(1,4)$. The major sink for heavy metals released into the surroundings are soils due to anthropogenic activities such as industrial wastes, automobile pollution and paints, fertilizers application and deposition (2 , 16, 23, 24 ). The contamination by heavy metal of soil increases risks and hazards to human and the ecosystem through food or direct contact, as soil-plant-human or soilplant-animal-human interaction is inevitable, leading to phytotoxicity, and decrease in agricultural yield causing food insecurity ( 28 , $29,30)$. Two major challenges of agricultural production in Oman which are salinity and drought. These are induced by industrial pollution and climate change effects. However, the main irrigation water sources available are aflaj (water channels that are driven by gravity used for irrigation) and groundwater. Over-exploitation of these sources increases salinity in water due to prolonged bioaccumulation, thereby shifting farmers' attention to other free water sources such as treated sea water effluents $(5,8)$. Oman were affected by salinity, while salt affected area within unsuitable agriculture is around $12.32 \mathrm{M}$ ha of the total geographical area of Oman. This makes it necessary to monitor the toxic elements in leaves and fruits ( 7 ). The application of treated water effluents to composted sludge is reported to cause accumulation of heavy metals in soil and plants due to leaching ( 25 ). Heavy metals are trace metals that have density more than $5 \mathrm{~g} / \mathrm{cm}^{3}$ and toxicity even if they present in low concentrations. In recent times, $\mathrm{Cd}$ accumulation increased in the coastal surroundings due to anthropogenic activities ( 40 ) Moreover, rapid industrialization creeping into agricultural areas has led to the transfer and accumulation of heavy metals to the soil, water and plants throughout the years (19 ). The affected areas' fruits production is threatened by pollution, which is transmitted to humans throughout food chain and can be harmful to the living organisms if the toxicity is above specified thresholds levels ( 3,30 , 43 ). Aside from the industrial pollution, other sources could be from pesticide application automobile emission ( $\mathrm{Pb}$ and $\mathrm{Cd}$ ) or waste from urban settlements ( 16,24 ). However, some of these heavy metals are essential to living organisms' e.g $\mathrm{Zn}, \mathrm{Mn} \mathrm{Mg}, \mathrm{Cu}$ and $\mathrm{Fe}$ but at very low concentrations. The plant uptake of heavy metal is dependent on $\mathrm{pH}$ of the soil, the total heavy metal concentration in soil surface, soil texture, cation exchange capacity and loss-on-ignition (22). The contamination of soil, water, plants, fruits or food by heavy metals is a major problem that needs attention. Heavy metals affect food chain trophic levels, from soils, plants to animals and even human. Consumption that is above certain threshold levels overtime is harmful to humans and plants ( 3, 30, 43 ). Heavy metals also affect ecosystem, aquatic and terrestrial through wastewaters, acid rain and runoff of rain-water to the rivers and oceans ( $30,42,33$ ). The major pathways for movement of the metals to the environment are atmosphere and water flow, resulting in sediments, ground water, and soil pollution ( 18 ). This raises concern on the relationship between heavy metals concentration in date fruits close to industrial areas and the industrial pollutants from factories in Oman. Even, if the concentration of heavy metals in the soil and groundwater around Omani factories is from the aerosols. This paper will study the bioaccumulation of heavy metals in soils and dates fruits near the industrial area of Al-Rusail in the Sultanate of Oman. The study will determine the concentration of heavy 
metals in fruits and groundwater as well as correlate heavy metal concentrations among soil, groundwater and date fruits.

\section{MATERIALS AND METHODS}

\section{Study area}

Al-Rusayl Industrial Estate, located in the Governorate of Muscat, 15 kilometers from Muscat International Airport, occupies 7.9 million square meters. The estate had expanded to 211 factories, from the initial 12 budding factories in recent years. Functional industries in the area produce wide spectrum of consumer as well as industrial-oriented products. It also provides services such as electricity, water, gas, sewage treatment, and the disposal of solid and other wastes.The study area is divided into three sites, which include farms near Oman Cement Factory, farms near the Al-Rusayl Industrial Estate, and control site farm. Each site has three sampled farms except the control site. See Figure 1,2 and 3 . The average distance among the sites is $15 \mathrm{Km}$.

\section{Study Design and Data Collection}

Analysis of Variance (ANOVA) did test if the (independent) variables; industrial site, farms and depths effects are statistically significant to the concentration distribution of $\mathrm{Ni}, \mathrm{Zn}, \mathrm{Cd}$, and $\mathrm{Pb}$ in the soil, water and fruits using Randomized Completely Block Design (RCBD). To determine the significance of the heavy metals, two parameters were chosen. These include the farm and the site of collection, serving as the replicates and sites as treatment blocks respectively. The ANOVA and least significant difference (LSD) was determined at 5\% using Genstat 17.1 statistical package Data was collected from three farms located within each site, namely Site 1 (Farms 1, 2 and 3), Site 2 (Farms 4, 5 and 6) and Site 3 (Farm 7 served as control). The three sites were based on the anthropogenic proximity of date fruit trees to industrial area, Cement Factory and the farmland. Heavy metals analyzed are Lead $(\mathrm{Pb})$, Cadnium $(\mathrm{Cd})$, Zinc $(\mathrm{Zn})$ and Nickel (Ni). Soil-water correlation coefficients were calculated with ncalculators.com using t-test method. The relationship was statistically significant at $\mathrm{p}<0.05$.

Sampling: Samples of soils, water and palm fruits (dates) were taken from 6 farms (3 farms near the cement factory and 3 farms near AlRusayl Industrial Estate) during 6 months. Fruit samples were collected from Khalass date palm at four stages as shown in Figure 4.The dust on each fruit samples was washed thrice with distilled water. After washing, all fresh fruit samples were weighed and left to dry in the oven at $105^{\circ} \mathrm{C}$ for 3 days. Dry weights were taken to determine the moisture content of the fruit samples. The cores or seeds were separated from edible parts. The edible parts (fruit tissues) were kept in the oven to complete dryness. The dry tissues were transferred to labeled-plastic containers after grounding. Samples of groundwater and soils were collected, from June to November 2016 in each farm. Soils were collected from three levels $(0-30 \mathrm{~cm}),(30-60 \mathrm{~cm})$ and $(60-90 \mathrm{~cm})$ in triplicates by using shovel and long digging bars, from each farm because the roots of the palm trees have deep penetration. The soils were sieved using $2 \mathrm{~mm}$ screens, fruits are dried using oven at temperature 105 degrees Celsius for 10 days to remove any moisture, and water samples were analysed in the laboratory at Ministry of Agriculture and Fisheries and Ministry of Regional Municipalities and Water Resources, Sultanate of Oman.

\section{Digestion of soil samples}

The grinded soil samples were digested according to Allen et al and as modified by Deribachew et al, 2015, one gram of each air dried sieved soil samples was placed on 250 $\mathrm{ml}$ digestion tube and $7 \mathrm{ml}$ of tri-acid mixture (HNO3, HClO4, H2SO4 (5: 1: 1) (v: v : v) ratio) was added. Then these tubes with their contents were placed on the digestion block at $100{ }^{\circ} \mathrm{C}$ for 40 minutes and then at $160{ }^{\circ} \mathrm{C}$ for 50 minutes until transparent solution was obtained. The digested samples were filtered using Whatman filter paper No. 42. The filtrate transferred to a $50 \mathrm{ml}$ volumetric flask and distilled water added to the mark. Triplicate of each soil samples were carried out together with blank digestion without the sample.

\section{Digestion of fruit samples}

The grinded fruit samples were digested according to Allen et al ( 5 ), with slight modifications on the procedure to obtain a clear or transparent solution. From each 
sample, $1 \mathrm{~g}$ was taken and placed in digestion tube and $7 \mathrm{ml}$ of tri-acid mixture $\left(65 \% \mathrm{HNO}_{3}\right.$ : 60\% $\mathrm{HCLO}_{4}:$ 93-98\% $\mathrm{H}_{2} \mathrm{SO}_{4}(5: 1: 1)(\mathrm{v}: \mathrm{v}: \mathrm{v})$ ratio) was added. The digestion tube with its contents was placed on digestion block at 420 ${ }^{\circ} \mathrm{C}$ for 45 minutes until transparent solution was obtained. The digested samples were filtered using Whatman filter paper No. 42. The filtrate was transferred to $50 \mathrm{ml}$ volumetric flask and deionized distilled water was added to the mark. This procedure was applied to all fruit samples and their triplicates and carried out together with blank digestion without the sample.

\section{Digestion of groundwater sample}

According to Apha (19), $100 \mathrm{ml}$ of well mixed-preserved groundwater samples was transferred into a beaker covered with watch glass and $5 \mathrm{ml}$ of concentrated nitric acid $\left(\mathrm{HNO}_{3}\right)$ was added. Then, the beaker was placed on hot plate and allowed to evaporate slowly at $80^{\circ} \mathrm{C}$ to about $15 \mathrm{ml}$. After that, the beaker was allowed to cool and another $5 \mathrm{ml}$ of nitric acid (HNO3) was added in the beaker and returned to hot plate. The heating and adding concentrated nitric acid ( $\mathrm{HNO} 3$ ) were continued until a transparent solution was obtained. Then the beaker was removed and allowed to cool down. The beaker walls and watch glass cover were washed with deionized distilled water. The solution was filtered through whatman filter paper No. 42 and the filtrates were transferred to $100 \mathrm{ml}$ volumetric flasks and diluted to the mark. This procedure was conducted for all groundwater samples.

\section{RESULTS AND DISCUSSION}

\section{Heavy Metals in Soils}

Cadmium (Cd): The $\mathrm{Cd}$ mean contents in soils of farms, both within the sites and among the depth, were significant at $(\mathrm{p}<0.05)$ but the mean decreased as the distance increases away from the factory area, except Farm (6) in site 2 $(0.00466 \mathrm{mg} / \mathrm{Kg})$, about $6 \mathrm{~km}$ away from the Oman Cement Factory.Although, farms within the industrial site did show high significance $(p<0.05)$, the interactions between and among the factor levels over period of six months at three different depth levels were not statistically significant. The highest interaction mean $(0.007117 \mathrm{mg} / \mathrm{kg})$ was in Farm (1) during the month of June at $0-30 \mathrm{~cm}$ (figure 5). This is not above the threshold set by WHO and/or
Omani authorities on the concentration of $\mathrm{Cd}$ in soils.

\section{Nickel (Ni)}

Nickel is the dominant element in the soil of all the studied sites. The concentration of $\mathrm{Ni}$ in soil decreased at $30-60 \mathrm{~cm}$ depths as the farms sites distances increases, except Farm (6) in site 2. Although both the farms and depths had high significant differences within the respective sites $(p<0.05)$, the concentration had a sharp increase at farm (6) that indicated presence of higher concentration of $\mathrm{Ni}$ in soils of farms in site 2. The mean (as shown in Figure 6) in $30-60 \mathrm{~cm}$ and $60-90 \mathrm{~cm}$ is higher than the $0-30 \mathrm{~cm}(1.017 \mathrm{mg} / \mathrm{Kg})$ to exposure of the soil surface at the first depth for nickel (Ni) in Farm (6) of cement factory site. The mean among the three sites also did differ in its concentration of the heavy metal. However, all the interactions indicated no significant difference except at the depth and farm interaction $(p<0.05)$. In general, there is a gradual decreasing pattern in heavy-metal content distribution at the depth levels as the industrial sites distance increases. This indicates that the concentration of $\mathrm{Ni}$ in soils around the industrial sites are within the standards in Oman, as well as the WHO standards for Ni in agricultural soils.

\section{Lead $(\mathbf{P b})$}

The amount of $\mathrm{Pb}$ in soils at different depths differed significantly $(\mathrm{p}<0.05)$ among the farms as well as in depths. Figure 7 showed the trend of the means at different depths. Unlike the Cd, the mean among the soil depths varies significantly as the distance increases from the reference sites. The cement factory farm sites had more zinc as the depth increases, while the industrial area (site 1) had more concentration of zinc at the top depths of the closest farm to the site $(0.14243 \mathrm{mg} / \mathrm{Kg})$. However, there was no significant difference in the months for $\mathrm{Pb}$ concentration. The interaction among the factor levels did not reveal any significant difference $(\mathrm{p}<0.05)$. The concentration of lead $(\mathrm{Pb})$ varied significantly among the farms at site 2 and between three sites. However, there was no significant variation among the farm in industrial sites. Farm (6) had the highest $\mathrm{Pb}$ concentration. When comparing the concentrations of $\mathrm{Pb}$ with $\mathrm{Ni}$ and then $\mathrm{Cd}$, the closest farms to industrial 
sites decreases in concentration at top depth level $(0-30 \mathrm{~cm})$ as the distance in proximity to pollution reduces, except at Farm (6) (Figures 5 to 7). In contrast with the Omani standards for $\mathrm{Pb}$ in soils, the soil depth in farm (6) was below the threshold as the level increases downward (Table 8).

\section{Zinc (Zn)}

Zinc, the heavy metal that is found in higher concentrations in the soils compared to the $\mathrm{Cd}$ and $\mathrm{Ni}$, had significant difference between the farms and within the sites as well as in depths across farms $(p<0.05)$. The interaction among the farm, months of collection and depths did not indicate any significant difference with time $(\mathrm{p}<0.05)$. However, the highest mean $(1.7905 \mathrm{mg} / \mathrm{Kg})$ was found in $0-30 \mathrm{~cm}$ of farm (1) in the industrial area site and lowest $(0.3677 \mathrm{mg} / \mathrm{Kg})$ mean recorded at the deepest depth in the control site (farm 7) (figure 8). Although, the farms had significant variation in the concentration of $\mathrm{Zn}$ within each site and compared to the control site with changes in climate factors due to seasonality shifts. Despite the high concentration of $\mathrm{Zn}$ in the nearest site to the factory, it is not yet above the level that will be harmful, but may increase with time if left unchecked.

\section{Heavy metal concentrations in groundwater:}

The results of heavy metal concentrations in water samples collected from the farmlands in all sites presented in figure 9. The concentrations of heavy metals $\mathrm{Zn}, \mathrm{Ni}, \mathrm{Cd}$ and $\mathrm{Pb}$ in the analysed water samples did not exceed the WHO (2011) and Oman standards for heavy metals (figure 9). ===Zinc is the most important heavy metal found in the water across the sites. The average concentration of $\mathrm{Zn} 0.01367 \mathrm{mg} / \mathrm{Kg}$ was the highest in farm 2 of Industrial site block. The zinc concentration $(0.01229 \mathrm{mg} / \mathrm{Kg})$ had no significant difference in the overall presence of the heavy metals of farm 5. Also, $\mathrm{Ni}, \mathrm{Pb}$ and $\mathrm{Cd}$ were discovered at varying concentrations but not significantly different among the farm sites and over the time of collection. Although there was a slight increase in concentration of nickel in farm 4, the increase in concentration was proportional in the first block, increasing from farm 1 to 3 and the second block decreasing from farm 4 to 6 . The mean concentration of the underground sampled water is a collection done in a period of six months (June to November). The lowest heavy metal concentration in the groundwater across the farms was found to be $\mathrm{Cd}(0.0001611 \mathrm{mg} / \mathrm{Kg})$ in farm 5.

\section{Correlation Analysis of Heavy Metal}

Table 1 summarizes the descriptive statistical results of the relationship between different physico-chemical properties and heavy metal concentrations in the soil. The relationships were analyzed by using Pearson's correlation coefficient to determine how soil properties influence heavy metal concentrations by distance in industrially polluted soils, water and fruits. Mean metal concentrations for $\mathrm{Cd}$, $\mathrm{Pb}, \mathrm{Ni}$ were all significant in the correlation table except $\mathrm{Zn} / \mathrm{N}$ and $\mathrm{Mg} / \mathrm{Ni}$ that had higher significant correlation $(\mathrm{p}<001)$. The correlation coefficients were slightly moderate between $\mathrm{K}$ and $\mathrm{Ni}$ as well as phosphorus $(\mathrm{P})$ and $\mathrm{Zn}$ with $\mathrm{r}$ values of 0.3233 and 0.3434 ; respectively. Similarly, moderate correlation was found between moisture content and $\mathrm{Zn}$ with $r$ value of 0.3792 present in the soil. The concentration of $\mathrm{Cl}$ also had positive relationship with $\mathrm{Pb}$. Other slightly moderate relationship is between zinc and magnesium (0.2438 ppm), but $\mathrm{Mg}$ had significant difference $(\mathrm{p}<0.05)$ with $\mathrm{Pb}$. On the other hand, sodium $(\mathrm{Na})$ had negative relationship with all the selected heavy metals, just as $\mathrm{Ni}$ relationship with $\mathrm{Na}, \mathrm{Cl}$ and $\mathrm{Ca}$ was reported as negative, despite showing significant level $(0.5096$ at $\mathrm{p}<0.05)$ with $\mathrm{P}$. Electrical conductivity had no positive association with all the selected heavy metals except $\mathrm{Pb}$. The correlation of $\mathrm{pH}$ with selected heavy metals did not change significantly $(\mathrm{p}<0.05)$ but had positive relationship with all the examined heavy metals. The water holding capacity of the soil is dependent on the moisture content. Moisture content showed positive relationship with all the metals but not with $\mathrm{Pb}(-0.0358)$. The level of significance $(p<0.05)$ in the relationship between $\mathrm{Cd}$ and $\mathrm{Pb}$ made it an exception to the highly significant correlation $(p<0.01)$ among all the selected heavy metals in the soil as seen in table 2. Meanwhile, the correlation between heavy metals in groundwater showed negative relationship, except that the $\mathrm{Ni}$ responded positively to 
electrical conductivity after indicating statistical difference $(\mathrm{p}<0.05)$ in table 3 . Furthermore, despite the non-statistical difference among all the heavy metals present, the correlation of heavy metals in groundwater and soil showed negative relationship between the heavy metals, but positive relationship was found in $\mathrm{Cd}$ in the soil and $\mathrm{Cd}$ in the groundwater (Table 4). The relationship between $\mathrm{Cd}$ and $\mathrm{Pb}$ was highly significant statistically, just as $\mathrm{Ni}$ and $\mathrm{Zn}$ are significant at $(p<0.01)$ in table 5 for testing correlation of heavy metals in fruits. The significant correlation of $\mathrm{Cd}, \mathrm{Ni}, \mathrm{Pb}$ and $\mathrm{Zn}$ indicates that the variables were derived from similar pollution sources as moving together (Faisal et al., 2014). The fruit's heavy metals correlation shows strong correlation between $\mathrm{Cd}$ and $\mathrm{Pb}$ at $(\mathrm{p}<0.01)$ and moderate correlation between $\mathrm{Ni}$ and $\mathrm{Zn}$. Cadmium and moisture content as well as $\mathrm{Pb}$ and moisture content show negative correlations (Table 5). The correlation between heavy metals in the fruits and soils is shown in table 6. Heavy metals in soils and fruits have positive correlation. Significant correlations were shown between $\mathrm{Ni}$ in the fruits and soil as well as $\mathrm{Pb}$ in the fruits and soil at $(\mathrm{P}<0.01)$. The $\mathrm{Zn}$ in the fruits and soils also had significant difference $(p<0.05)$. On the other hand, the correlation between heavy metals in the groundwater shows negative correlation, except $\mathrm{Zn}$ in fruits and groundwater which showed positive correlation but not significant at $5 \%$ level of significance (Table 7).

pH Scale and Electrical Conductivity (E.C): The general relationship between $\mathrm{pH}$ and relationship indicated a positive relationship. The $r$ value is more than 0.5 (See Figure 5.23) in the $\mathrm{pH}$ scale and electrical conductivity correlation. The linear equation showed the closeness of the values to the intercept. The farms closer to the sites had more conductivity than the farms far from the sites.

\section{Bioconcentration Factor}

The ability of the plant to transfer the metals from the soil can be estimated by bioconcentration factor. It is the quotient of total metals in the plant or in fruits to soil substratum (Rai et al., 2010). The bioconcentration factor for fruits is shown in the figure 10.Industrial farms sites showed increasing trend in the $\mathrm{Cd}$ and $\mathrm{Pb}$ as the distance widens. Cadmium tends to have more bioconcentration than other observed heavy metals across the farms. The bioconcentration factors of cadmium were highest in farms 3, 4 and 6 , which were greater than 1 . This indicates that the concentrations of cadmium $(\mathrm{Cd})$ in fruits were higher than that in the soils. It can be inferred that the soil is not the only source of heavy metal contamination in the date palm fruits that it may be absorbed from air deposition. In addition, cadmium mobility is higher than other elements and can be easily absorbed by plants (Yan et al., 2012).The Ni was the lowest, followed by $\mathrm{Zn}$ with more concentration in cement factory sites (Site 2). The uptake capability from soil to the palm trees was in this order $\mathrm{Cd}>\mathrm{Pb}>\mathrm{Zn}>\mathrm{Ni}$. The result revealed that increasing heavy metal contents of the soils may increase the mobility and plant uptake of these metals. Meanwhile, all the results in the graph are below threshold level (Table 8 of WHO and Indian authorities' standard for heavy metals concentration in plants.

\section{Soil properties}

Soil $\mathrm{pH}$ is the most important soil property. The solubility of many elements (plant nutrients and heavy metals) depends on it. The $\mathrm{pH}$ values of the soil samples were ranged in narrow range $(7.1-7.74)$ which suggest that soil is in neutral to slightly alkaline condition. The analysis of electrical conductivity of the soils showed that it varied significantly with the depths of the soils and between the farms. farms $2,3,4,5$ and 6 were found to have the highest electrical conductivity. However, farms 1 and 7 had the lowest electrical conductivity. According to Patel (2015) and as showed in farms 3, 4 and 5 were moderately saline. However, farms 2 and 6 were slightly saline and farms 1 and 6 were salt free. The top soil had the highest electrical conductivity. Generally, it decreased with the depths of the soils. The analysis of the percentage of nitrogen content in the soils showed that most of these soils have low nitrogen levels. This indicated that Omani soils have low nitrogen contents.

Heavy Metals in Soils: The findings indicated a relationship between the concentration of heavy metals in fruits and the soils. Reports from different studies pointed frequent 
agricultural practices such as ploughing, harrowing and fertilization making the topsoil compaction in the farm sites spatially different as it affects distribution pattern of heavy metals $(36,39,44)$. The cement factory had more mean concentration of the heavy metals distributed around the sites; the nearest farm to the industrial area recorded the highest heavy metal concentration. Additionally, the reduction in heavy-metal concentrations in the soils as we dig deeper in most of the farms was also reported by Hamid (21) in Iran industrial zone study of contaminated soils and Kumar et al. (26) study of contaminated soils within the cement factory located areas. Kumar et al. (26) elaborated on the heavy metals from cement factory like nickel and lead, to be hazardous to the biotic environment, with impact on the agriculture and ecosystems. However, Hamid (21) reported the non-significant of heavy metals on intercropping but also agreed that heavy metals such as $\mathrm{Pb}$ and $\mathrm{Cd}$ can have high significant effect on soils at different locations if not checked in Iran. Aldjain et al. (6) also reported spatial variation in heavy metal amount at different locations in Saudi Arabia and concluded that exposure may not be induced by industrial pollution but also the need to consider other environmental factors as seen in farms 5 and 6 in this study. This may be due to other environmental factors affecting agricultural production as reported in the previous study on heavy metals in arid and coastal areas $(18,38)$.

\section{Accumulation of heavy metals in water with pH and E.C}

The accumulation of heavy metals is dependent on the amount of pollution released to the ecosystem in Al-Rusayl industrial areas. Al-Busaidi et al. (5) and Abbass and Hassan (2) confirmed that in the study of concentrations of few heavy metals in waste water and in ground water in the Middle East region. His results correspond with this finding that concentration of heavy metals in the ground water of Oman is within the permissible limits set by international standards (WHO 2007), but not independent of the pollution in the surroundings. In another research, Al-busaidi et al. (5) explained that Oman's safety regulation had contributed to the water and seafood control system which meets the national and export market. The $\mathrm{pH}$ in this study also was close to neutral level in the samples of all the parameters observed. This implies that Omani water heavy water presence is not harmful to the populace. AlMusharafi et al. (9) conducted similar contamination by industrial effluents and sludge relative to heavy metals and reported $\mathrm{Zn}, \mathrm{Cr}, \mathrm{Cu}$ and $\mathrm{Ni}$ not significantly different. Al-Musharafi et al. (9) also examined heavy metal contamination from treated sewage effluents contaminating water bodies and soil surface. Although, Baawain et al. (15) reported that electrical conductivity and biological heavy metals are within the Omani Standards (OS) based on analysis of treated water effluents from different sources in the three selected regions of Oman. This further supports the findings in this report that the bioconcentration of heavy metals sampled in the farm sites are gradually moving above threshold level recommended by Omani authorities.

\section{Uptake of heavy metals in the different stages of fruits}

In this study, higher levels of $\mathrm{Zn}$ and $\mathrm{Pb}$ indicate the increasing industrialization and uncontrolled urbanization. The increasing concentration of $\mathrm{Zn}$ in samples of soils date palm fruits collected might be due to the presence of production factories and cement factory as well as traffic emissions within the vicinity of the area. This finding agrees with by the work of Aldjain et al. (6) and AlShayeb et al. (13), who reported high level of $\mathrm{Pb}$ released in the environment due to the large consumption of leaded fuel by road vehicles had led to air pollution. The concentrations of $\mathrm{Cd}$ and $\mathrm{Ni}$ lead to contaminate the environment by aerial deposition on available and exposed fruits (27). Williams and Pillay (43) had reported excess $\mathrm{Cd}$ and Ni could lead to toxicity and serious environmental impact on date palms in the Middle East, including Oman. Shahin and Alhajoj (38) also reported a similar finding in which there was no significant difference in the fruits, although a huge significant difference was found between the treated water and irrigated water for heavy metal content. Al-busaidi et al. (8) had similar work on irrigated lands explained the position of ground water and in relation to heavy 
metals. However, other researchers also reported significant increase in the concentrations of metals in irrigated soils of fruits farms. For instance, El Mardi et al. (8) showed significant differences in the results of heavy metals found in irrigated cultivation with treated water. These differences, according to the researchers, were related to the plant species rather than location and age of the date palm. Whereas, longer exposure to treated water did not show significant effects on fruit minerals, including heavy metals. They also reported that the concentration of various minerals in different fruits other than date palm are influenced by the source of irrigation. The results in this study showed that there was a significant correlation between soil and fruit at Khalal stage concentration of $\mathrm{Ni}$ $\left(0.0005 x+0.0019, R^{2}=0.6571\right)$. Overall, the relationship between fruits and soils had the heavy metals on the positive side. According to Al-busaidi (5) and Al-Sahaf et al. (12), it may be attributed to the ability of the crops to translocate certain elements within the plants. Although, Abd-Elfattah et al. (2) also reported that contents in heavy metals of fruits produced by treated wastewater are significantly different from Nile river water used in irrigation in two seasons.

\section{Correlation and bio concentration factors}

The correlation coefficient among the heavy metals showed a skewed relationship with only $\mathrm{Zn}$ and $\mathrm{Pb}$ yielding positive result. This implies that the association is with other anions to have tremendous effect as pollutant on plants, soil and water $(15,13,37)$. The relationship between the elements and the heavy metals showed significance at $5 \%$ and 1 $\%$ for $\mathrm{Zn}$ versus $\mathrm{N}$ and $\mathrm{Zn}$ versus $\mathrm{P}$; respectively. The results also indicated a positive relationship among some non-metals and metals. This corresponds with the report of elements (30), which explains the impact of bio concentration of heavy metals are most likely to affect our ecosystem up to through the benthic pathway if not checked. Chojnacka et al. (17) also reported that statistically significant correlation coefficients were determined between fractions of soil and content in plant in heavy metals study. The study provided an evaluation of the soil-plant transfer factor for a given metal in plants. Soil physic - chemical variables observed including electronic conductivity, $\mathrm{pH}$, sodium adsorption ratio, organic matter, and non-metals indicated a positive correlation (Table 1). Al-Rashdi et al. (11) reported no difference in concentration of heavy metals between the different blocks of farms in relation to the bio concentration factors. However, it was reported that the farm soils were saline in nature. In general, metals bio accumulate more in the soil than in the fruits. Interestingly, the $\mathrm{Cd}$, which was recorded with the least concentration of salts in soils, had translocated most of heavy metals to the fruits. The $\mathrm{pH}$ was ranging from 6.62 to 7.52. According to Food and Agriculture Organisation, when the soil is saline, the $\mathrm{pH}$ is less than 8.2 and more often near neutrality. The data obtained in this research indicated increase in the heavy metals concentration with the deceased distance of the farms from the industrial sites. The high metal concentration in soil, groundwater and fruits was mostly due to the density of air pollution, a major medium of heavy metal contamination. The mean concentration of the heavy metals as the depth of the farmland sites decreases were ordered as follows: $\mathrm{Ni}>\mathrm{Zn}>$ $\mathrm{Pb}>\mathrm{Cd}$. The lowest mean values of metal concentrations were found at the control farmland (block) compared with the farmlands within the two selected sites (blocks), but the metal concentrations found at farmlands close to the factory sites were highest. The results showed a significant aerial deposition on the soil surface and groundwater for the metals, resulting from contamination and leaching overtime. The concentrations of heavy metals in the groundwater was found to be in this order $\mathrm{Zn}>\mathrm{Ni}>\mathrm{Pb}>\mathrm{Cd}$, and in fruits in this order $\mathrm{Zn}>\mathrm{Pb}>\mathrm{Ni}>\mathrm{Cd}$ The statistical analysis, and correlation analysis were tools in identifying the variation of metal in the samples. The presented results show that date palm farmlands are exposed to an inexpensive biomonitor of heavy metal contamination in areas close to industrial pollutions. The pollution may lead to significant loss of agricultural yield and contaminated food if not checked. The results of this study indicate that soils, water and fruits contained heavy metals within the permissible limits of WHO, FAO, Indian and Omani standards. 


\section{Recommendation}

Further research is needed not only to assess the spatial distribution of more metals in farmlands but also to evaluate at a smaller scale, with more fine sampling methods to check any change or increase in chemical elements in the sites overtime. Different waste disposal methods using low cost processing machines as seen in Sudharmaidevi et al. (41) should be encouraged. Environmental impact assessment prioritized before establishment and expansion of factories within the areas. The farms in the surrounding areas (less than $1 \mathrm{~km}$ ) should be monitored concurrently and the produce (dates) sold at Al-Mawaleh market inspected by food authorities. Furthermore, the role of agricultural research and extension and agricultural extension in educating farmers as well as conducting researches on the effects of contaminants, either from vector-borne diseases or metal contamination cannot be over-emphasized to avoid irredeemable. In addition, dates should be washed by water before consumption and before storage to avoid any contamination by these metals. AlShayeb (13) reported that washing the fruits by water can remove $80 \%$ of the lead and can reduce the lead content in fresh dates.

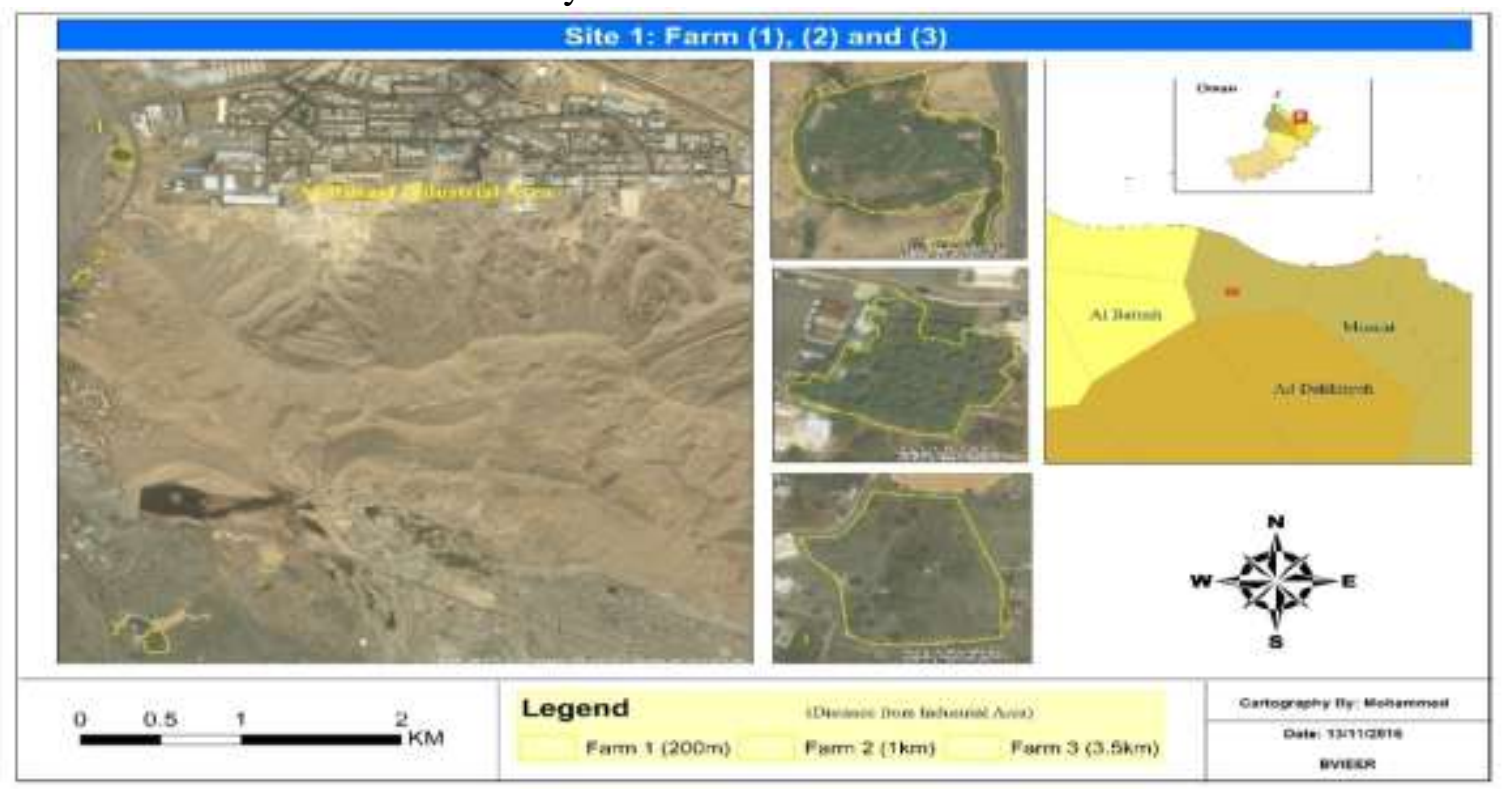

Fig 1. Site 1 outline map showing the farms near Al-Rusayl Industrial Estate, Sultanate of Oman.

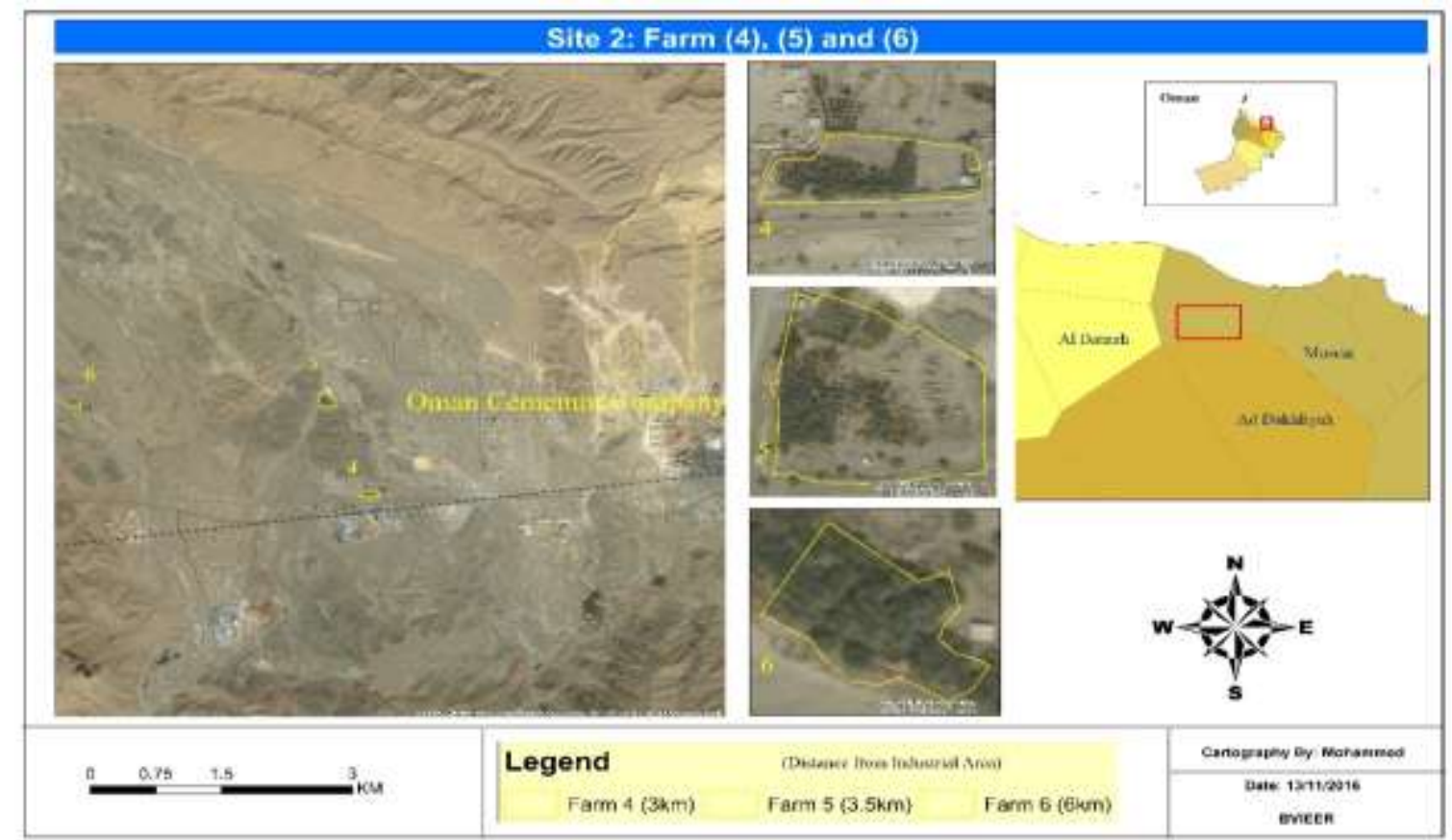

Figure 2. Site 2: an outline map showing the farms near Oman Cement Company, Sultanate of Oman. 


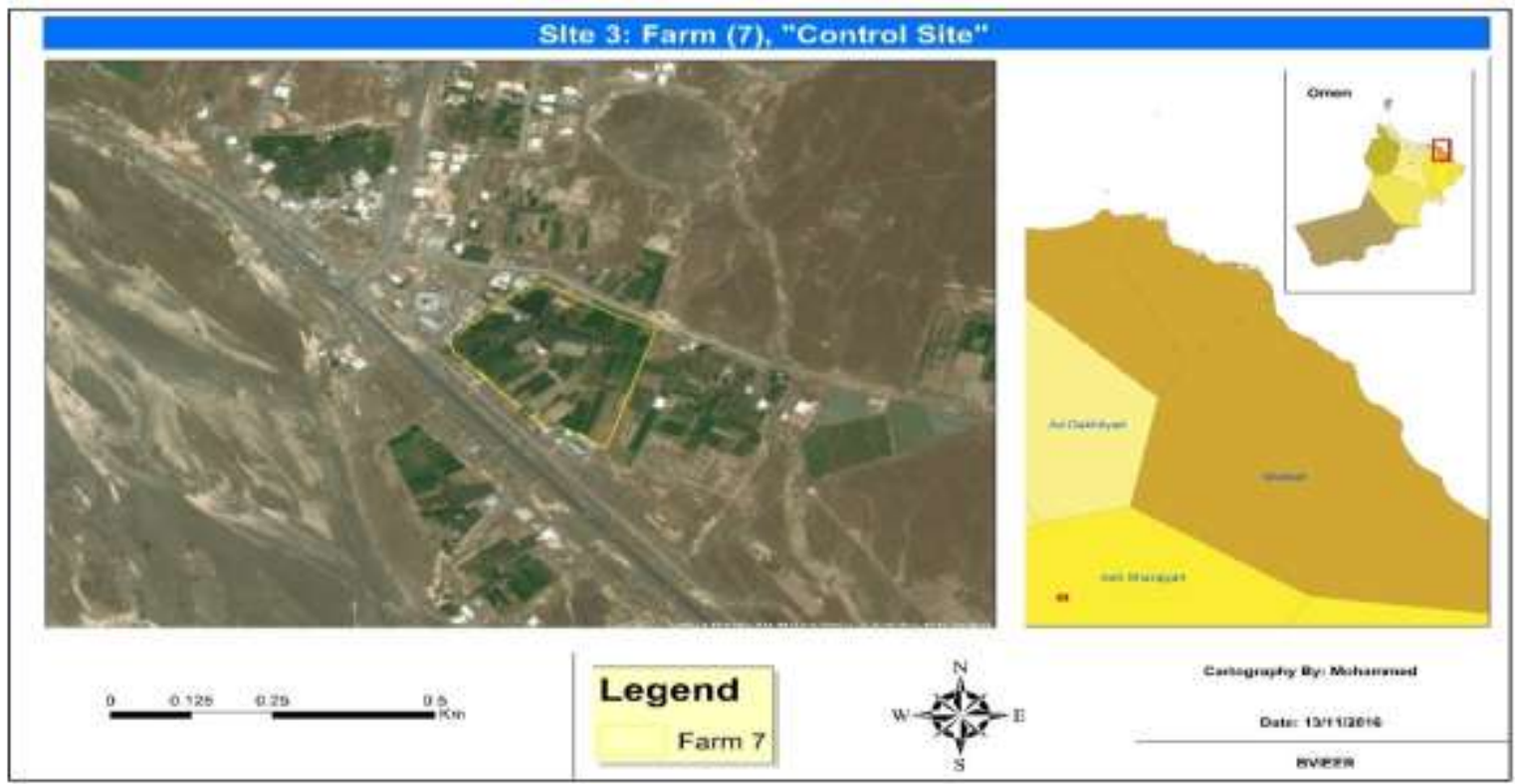

Fig 3. Site No.3 an outline map showing the farm serving control farm, Ibra, Al-Hayma, Sultanate of Oman.

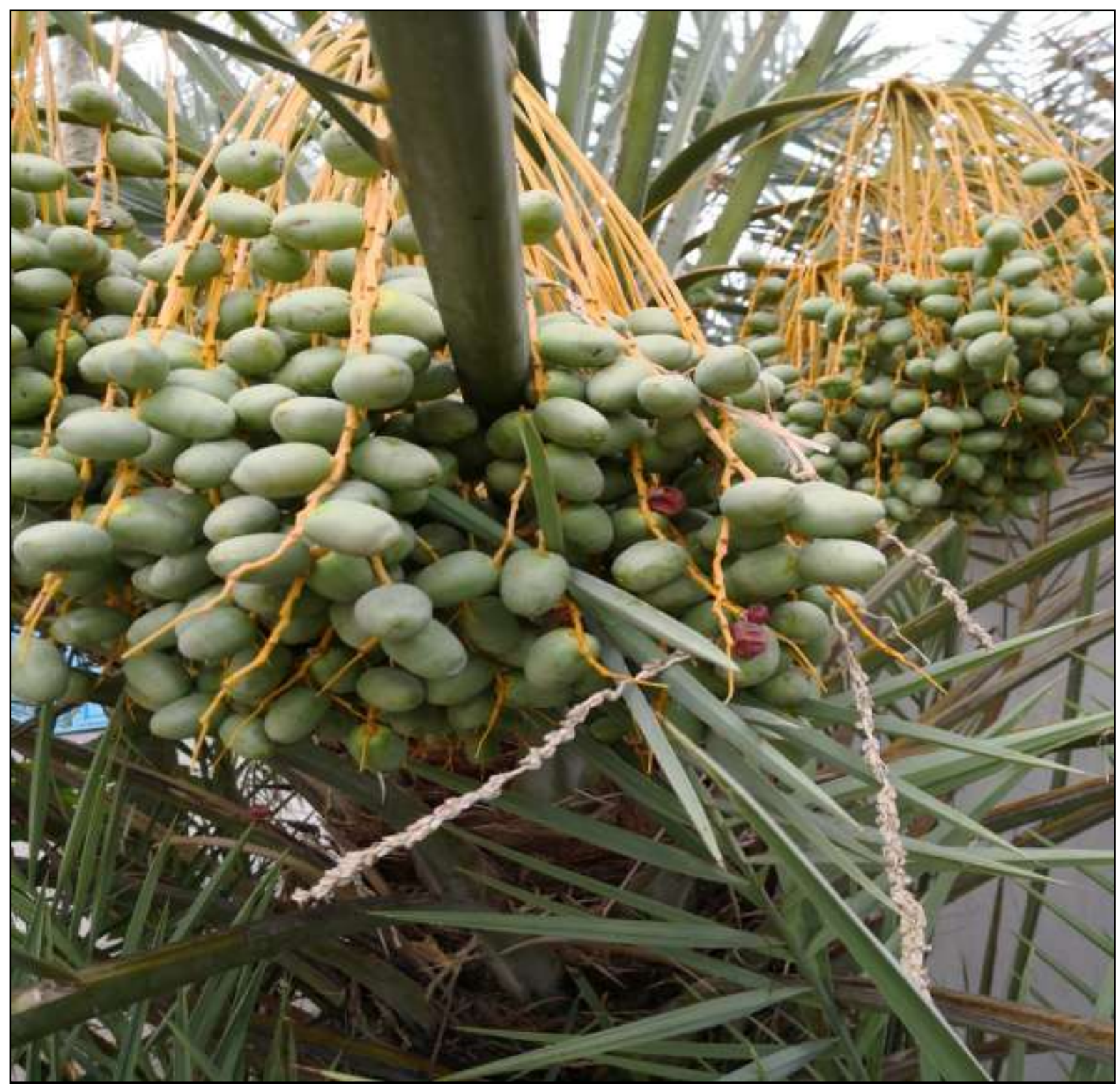

Khalal Stage 


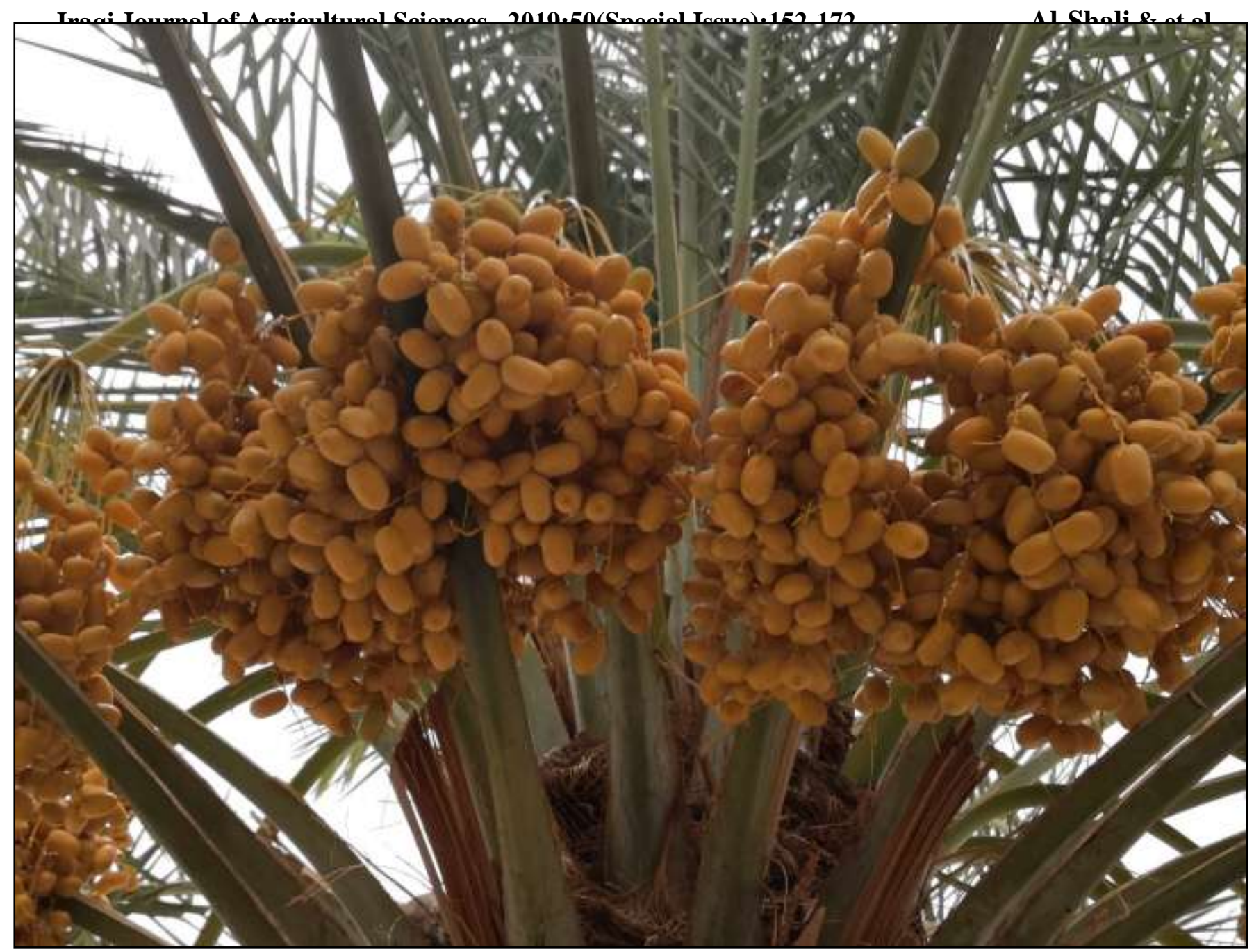

Biser Stage

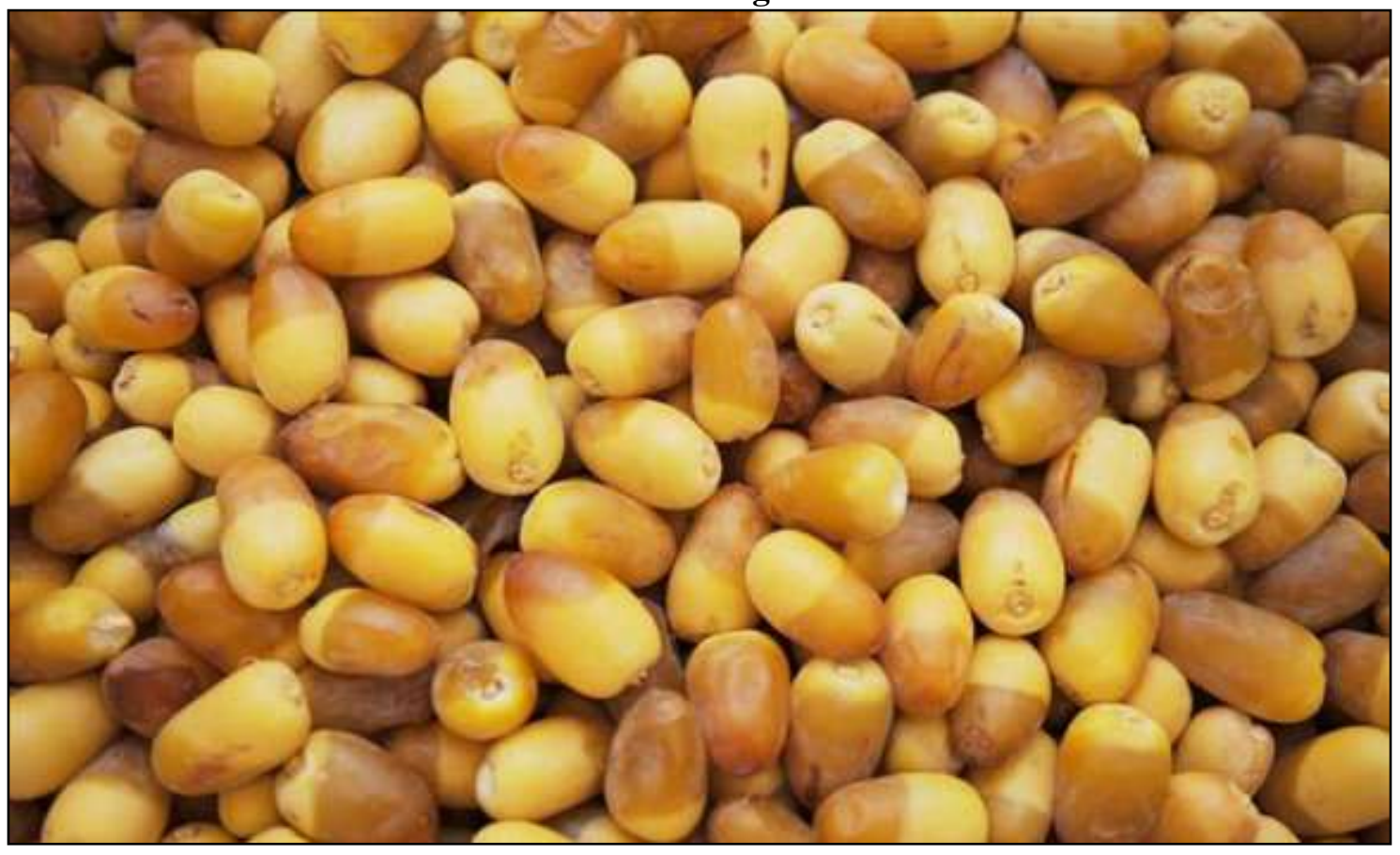

Rattab Stage 


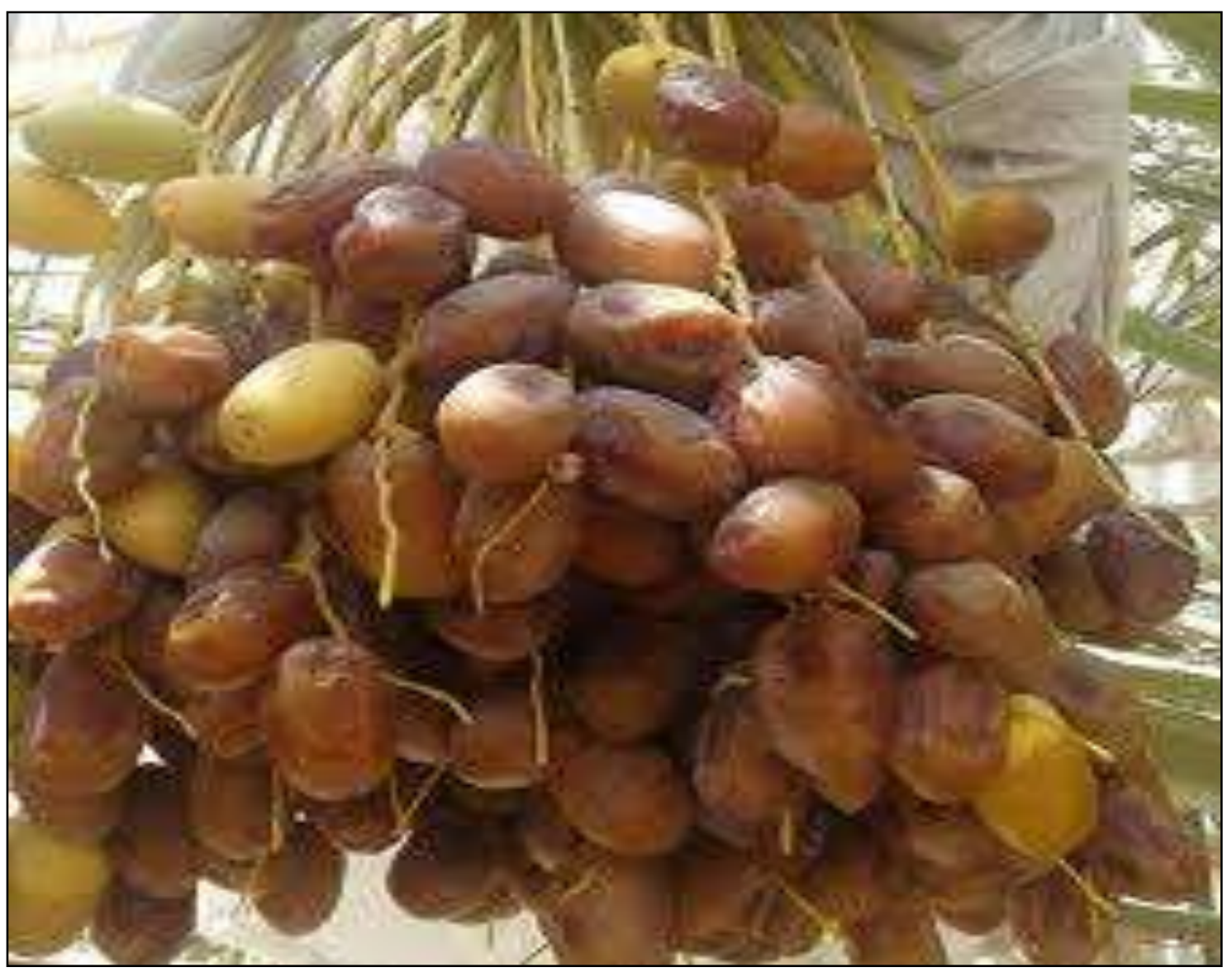

Tamar stage

Figure 4. The stages of the Palm fruits, including Khalal, Biser, Rattab, and Tamar respectively.

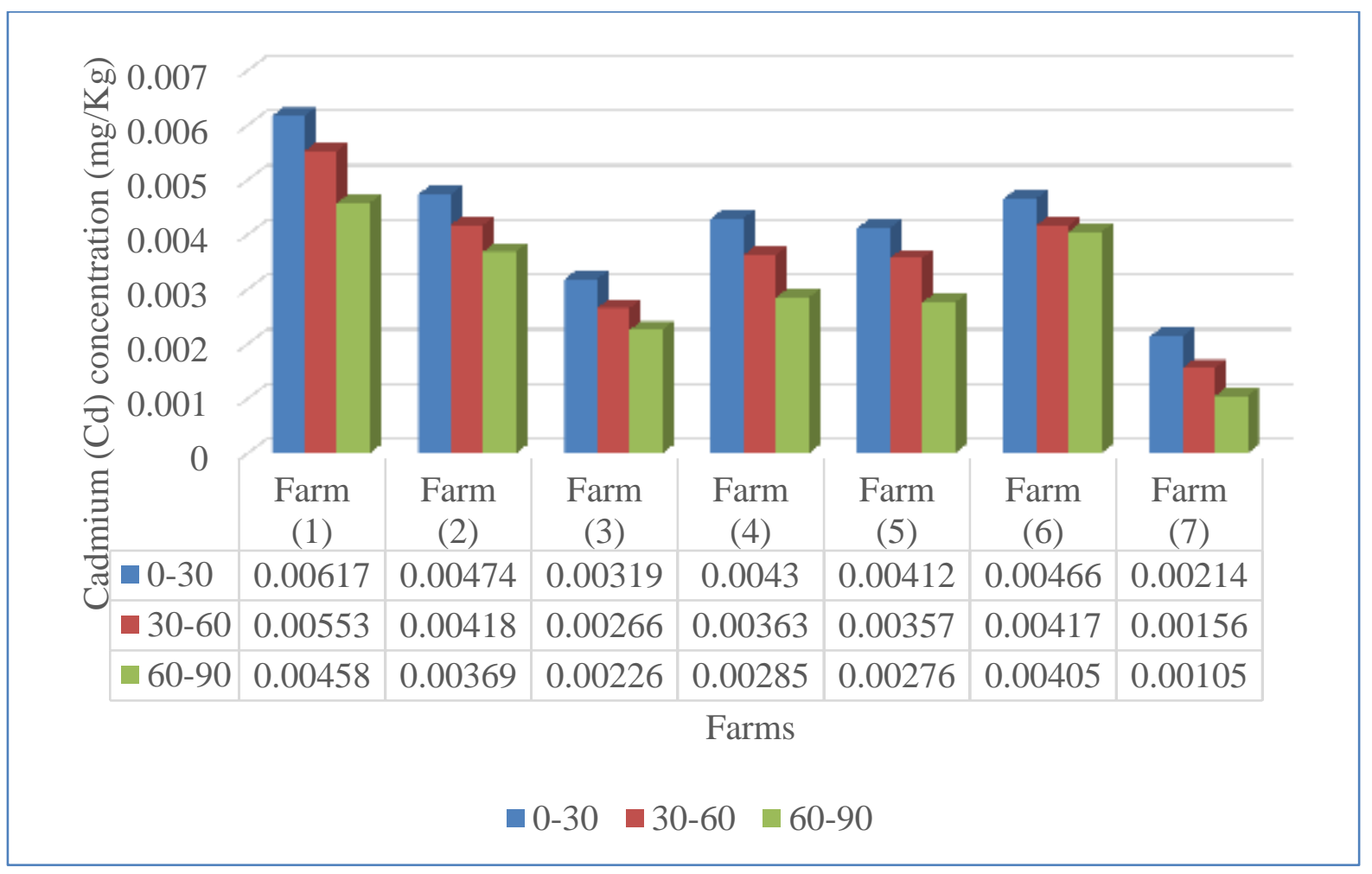

Figure 5: The mean concentration of cadmium $(\mathrm{Cd})$ in the soil at different depth. 


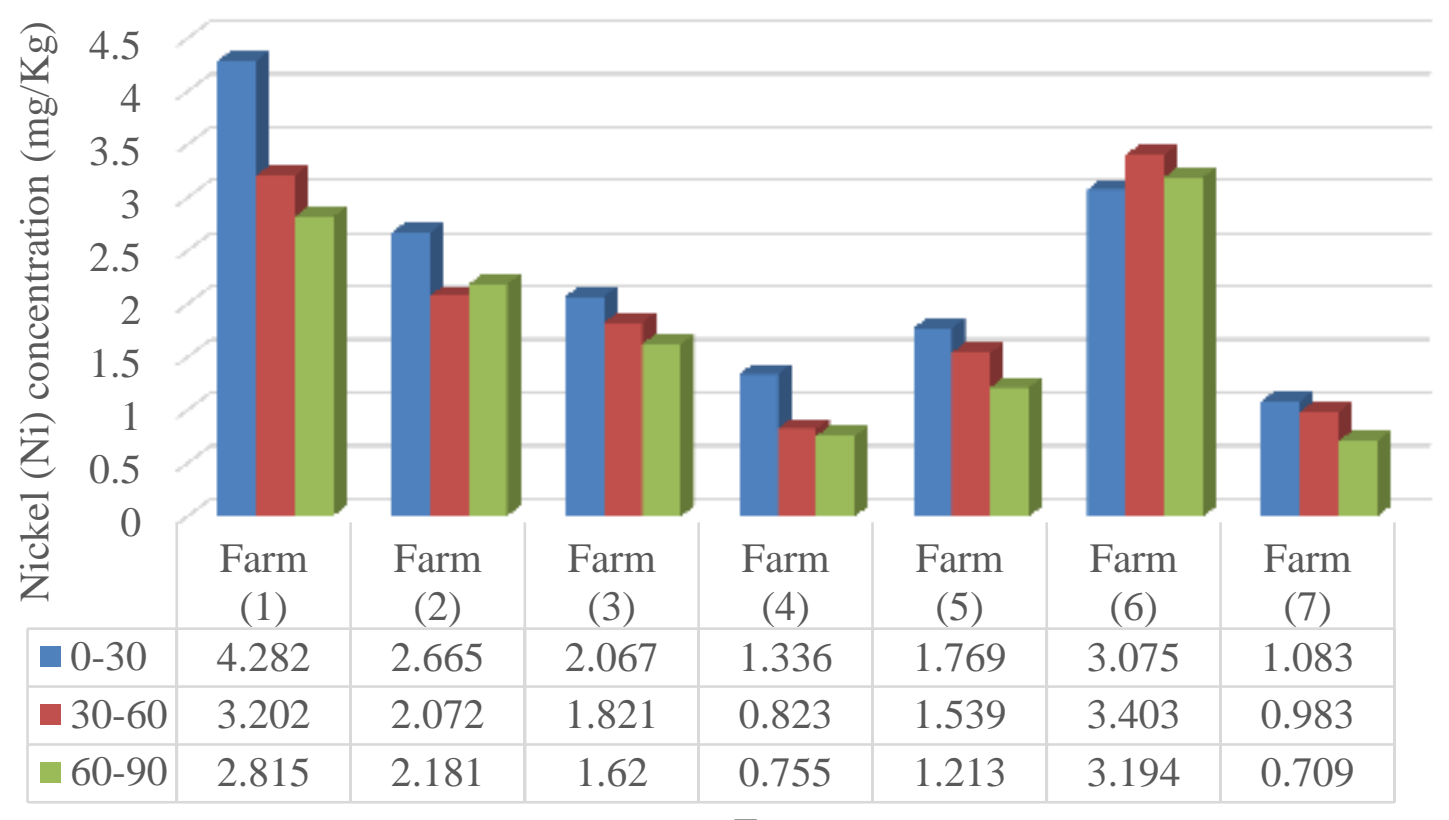

Farms

$$
\square \text { 0-30 } \square \text { 30-60 } \square \text { 60-90 }
$$

Figure 6: The mean concentration of nickel (Ni) in the soils at different depths.

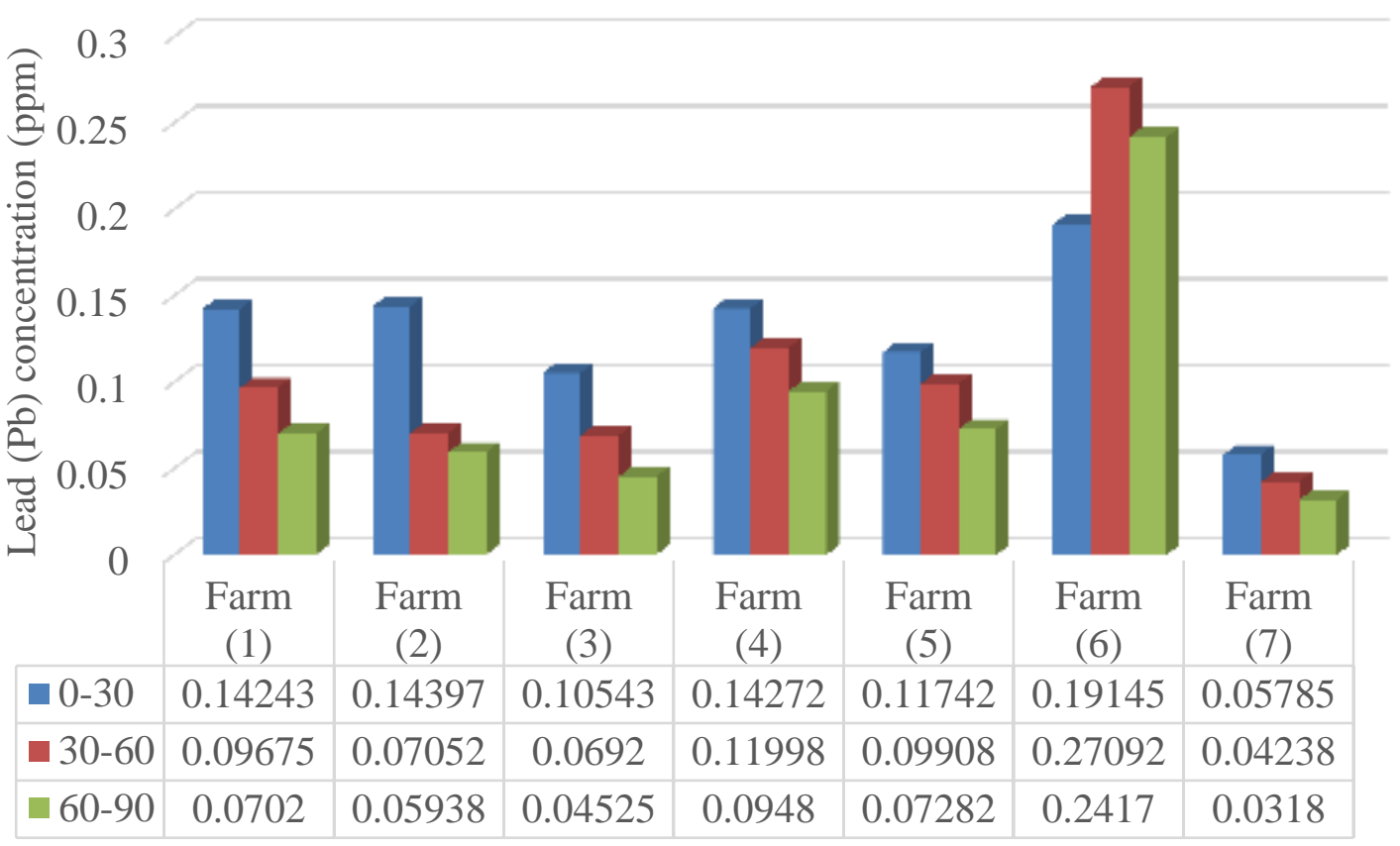

Farms

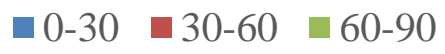

Figure 7: Mean concentration of lead $(\mathrm{Pb})$ in the soils at different depths. 

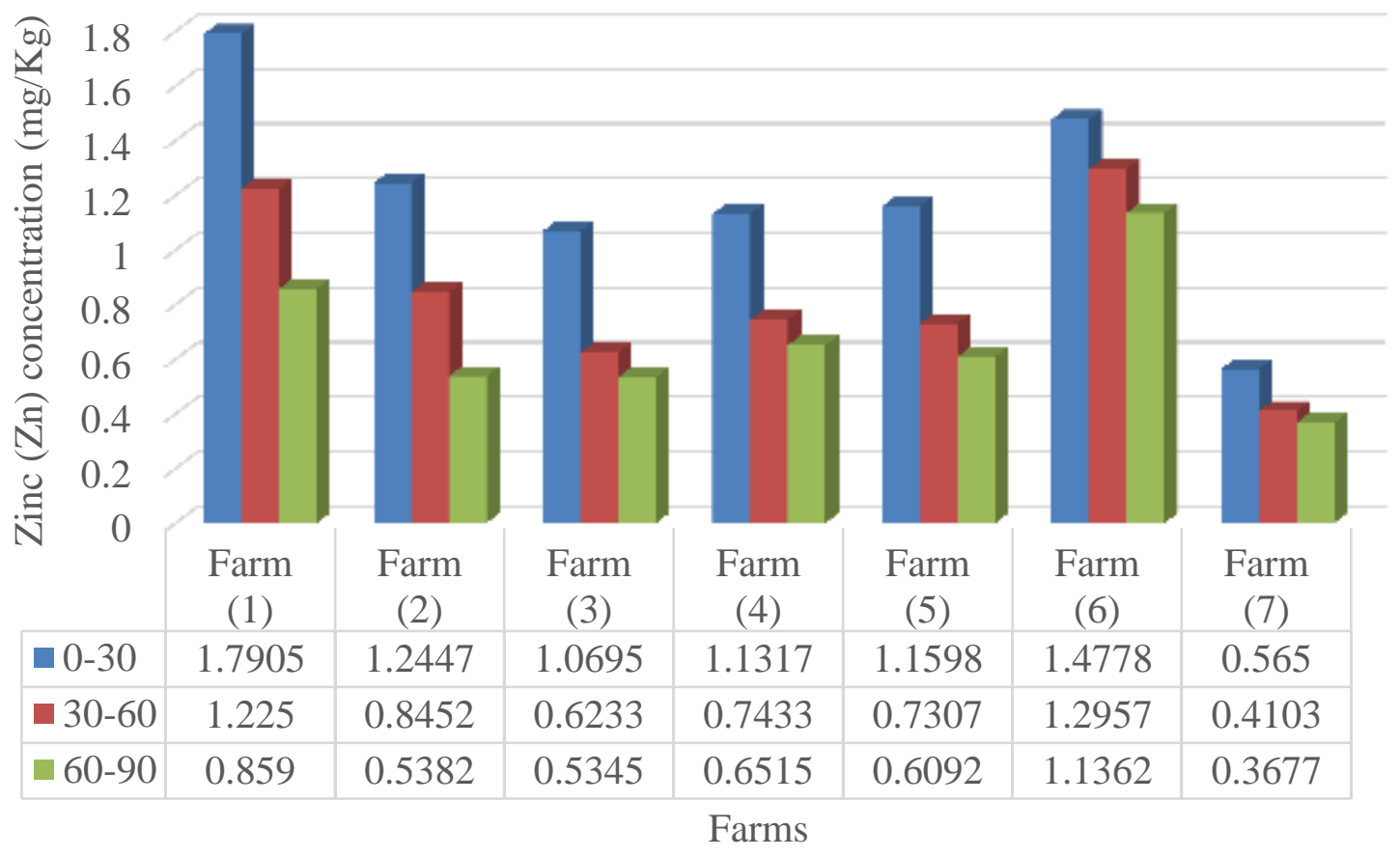

$$
\square-30 \quad \text { - 30-60 } \square 60-90
$$

Figure 8. Mean concentration of zinc $(\mathrm{Zn})$ in the soils at different depths.

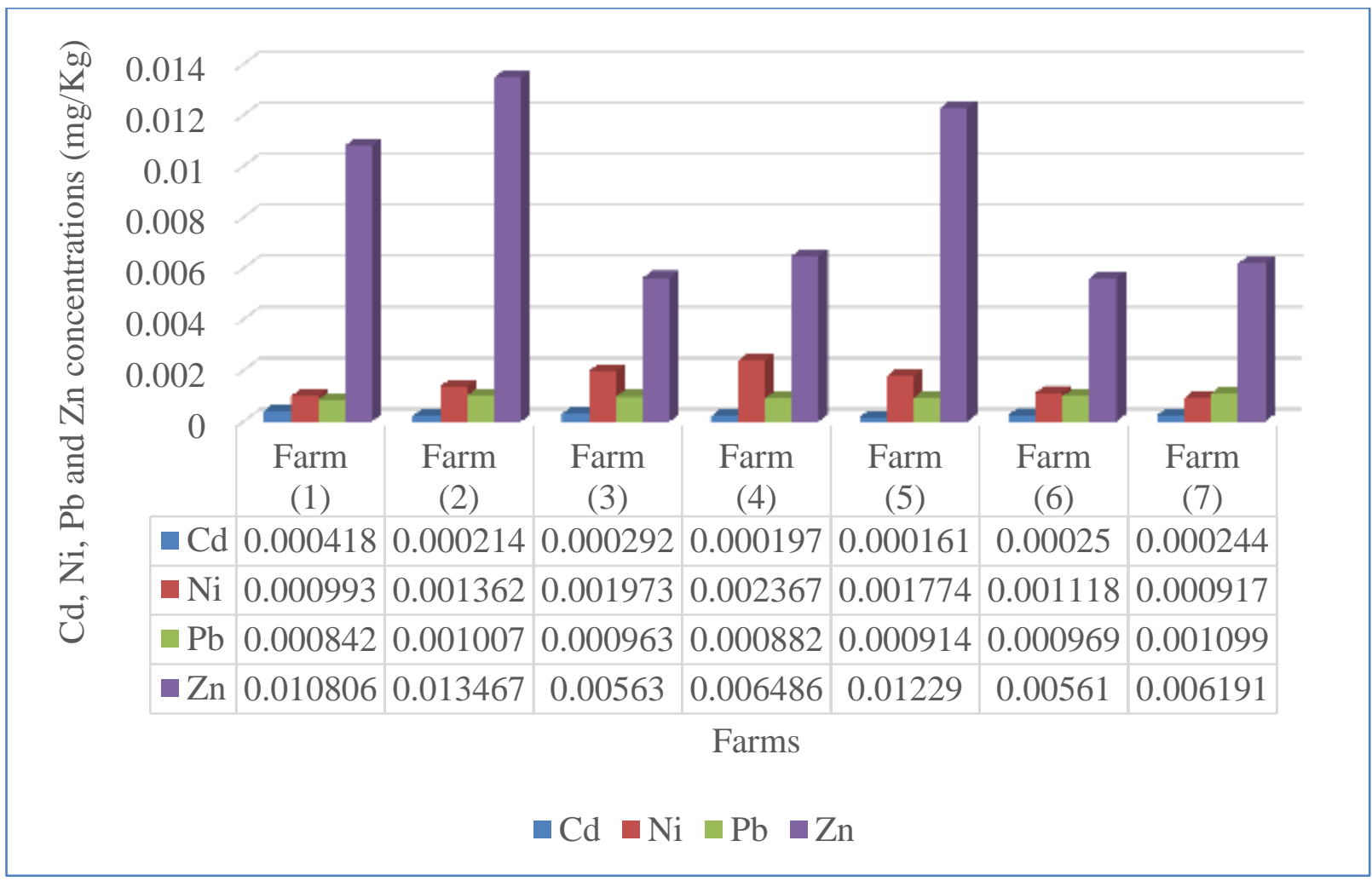

Figure 9: Heavy Metal concentrations in groundwater in all the farm sites. 


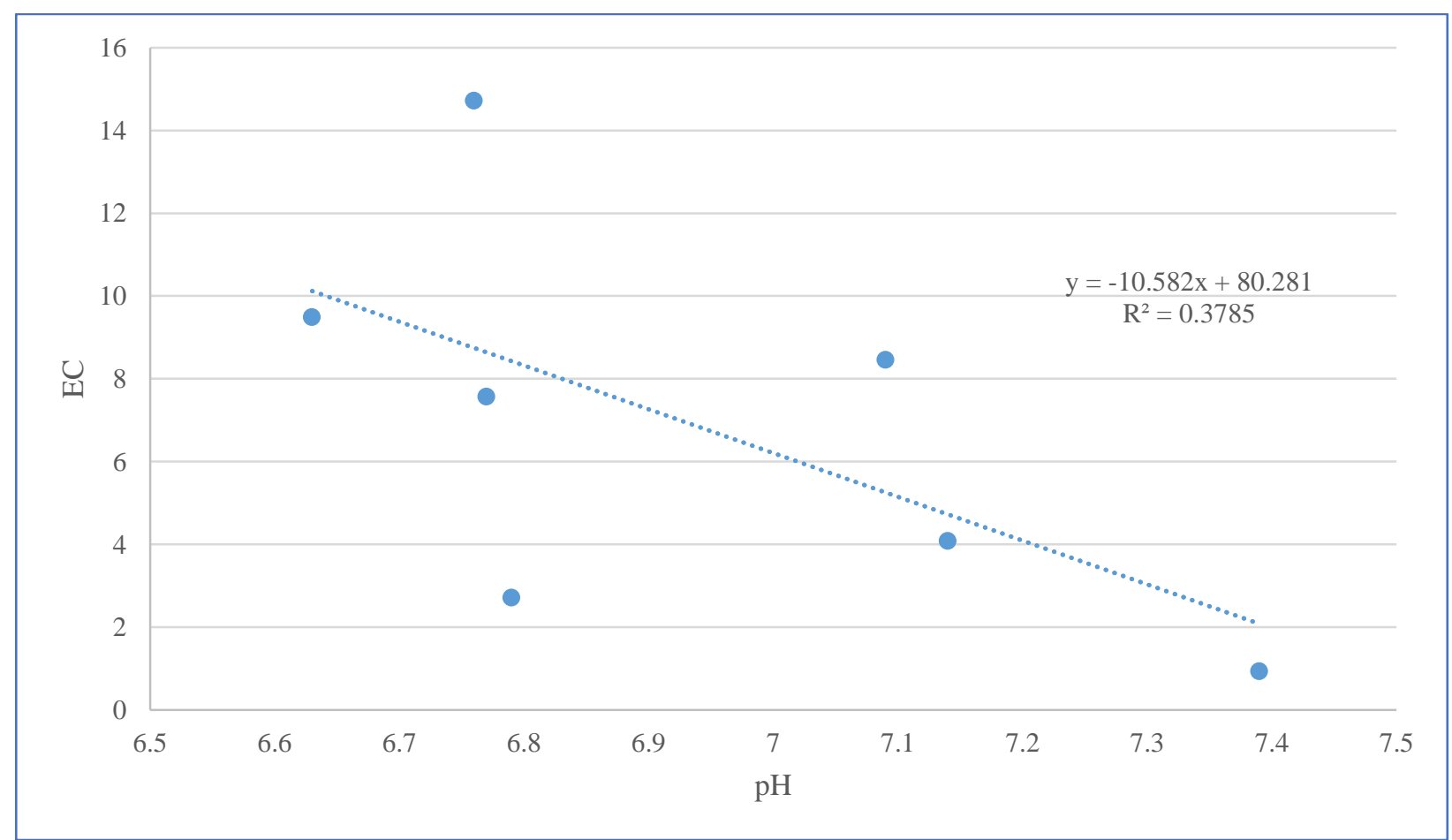

Figure 10: Correlation analysis among all farms sites showing the $\mathrm{EC}(\mathrm{mS} / \mathrm{cm})$ and $\mathrm{Pb}$

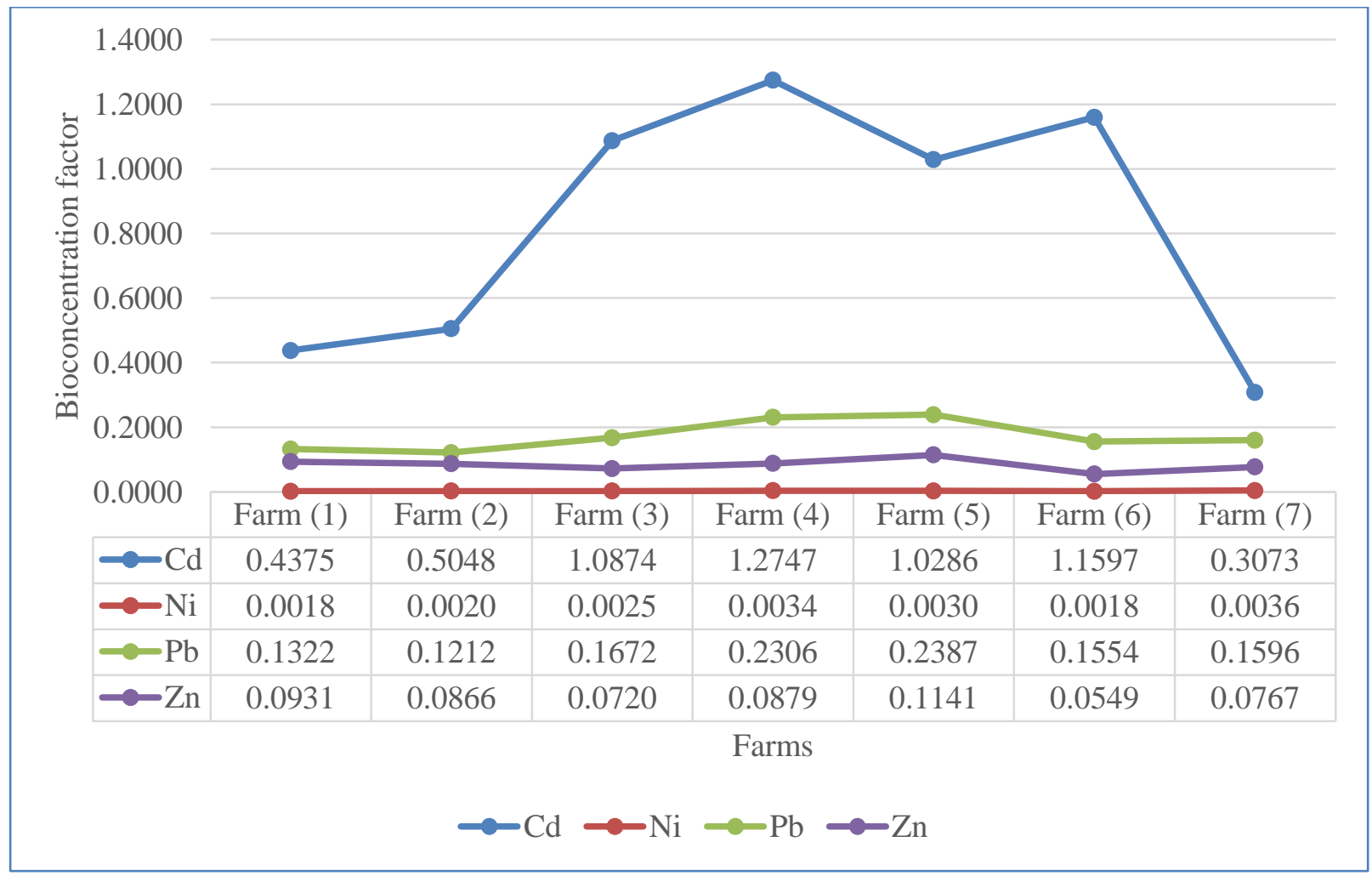

Figure 11. Bioconcentration factor of heavy metals. 
Table 1. Correlation of heavy metals with parameters in the soil:

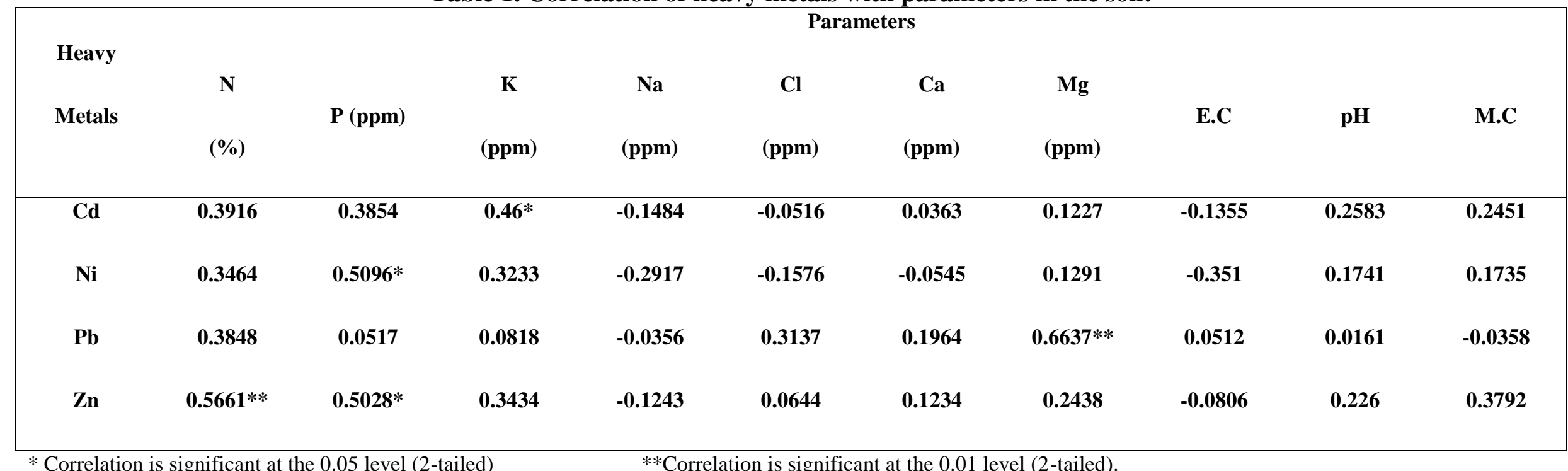


Table 2. Correlation of heavy metals in the soil

\begin{tabular}{|ccccc|}
\hline $\begin{array}{c}\text { Heavy } \\
\text { metals }\end{array}$ & $\mathrm{Cd}$ & $\mathrm{Ni}$ & $\mathrm{Pb}$ & $\mathrm{Zn}$ \\
\hline $\mathrm{Cd}$ & 1.0 & & & \\
$\mathrm{Ni}$ & $0.8052 * *$ & 1.0 & & \\
$\mathrm{~Pb}$ & $0.546^{*}$ & $0.607 * *$ & 1.0 & \\
$\mathrm{Zn}$ & $0.8696 * *$ & $0.8195 * *$ & $0.729 * *$ & 1.0 \\
\hline
\end{tabular}

* Correlation is significant at the 0.05 level (2-tailed).

** Correlation is significant at the 0.01 level (2-tailed).

Table 3. Correlation of $\mathrm{Cd}, \mathrm{Ni}, \mathrm{Pb}$ and $\mathrm{Zn}$ in the groundwater:

\begin{tabular}{|ccccccc|}
\hline & $\mathrm{Cd}$ & $\mathrm{Ni}$ & $\mathrm{Pb}$ & $\mathrm{Zn}$ & $\mathrm{pH}$ & $\mathrm{E.C}$ \\
\hline $\mathrm{Cd}$ & - & & & -0.0671 & -0.2128 \\
$\mathrm{Ni}$ & $-\mathbf{0 . 3 9 3 7}$ & & & -0.7611 & $0.8143^{*}$ \\
$\mathrm{~Pb}$ & -0.242 & -0.3377 & & & 0.7459 & -0.408 \\
$\mathrm{Zn}$ & -0.0649 & -0.1303 & -0.2001 & - & -0.1233 & -0.0528 \\
\hline
\end{tabular}

* Correlation is significant at the 0.05 level (2-tailed).

** Correlation is significant at the 0.01 level (2-tailed).

Table 4. Correlation of heavy metals in the soil with that in the groundwater:

\begin{tabular}{|ccccc|}
\hline $\begin{array}{c}\text { Heavy metals } \\
\text { in water }\end{array}$ & $\mathrm{Cd}$ & $\mathrm{Ni}$ & $\mathrm{Pb}$ & $\mathrm{Zn}$ \\
\hline $\mathrm{Cd}$ & $\mathbf{0 . 3 7 7 8}$ & & & \\
$\mathrm{Ni}$ & & -0.5146 & & \\
$\mathrm{~Pb}$ & & & -0.2339 & \\
$\mathrm{Zn}$ & & & & -0.2001 \\
\hline
\end{tabular}

* Correlation is significant at the 0.05 level (2-tailed).

** Correlation is significant at the 0.01 level (2-tailed).

Table 5. Correlation of heavy metals $(\mathrm{Cd}, \mathrm{Ni}, \mathrm{Pb}$ and $\mathrm{Zn}$ ) in the fruits:

\begin{tabular}{|cccccc|}
\hline $\begin{array}{c}\text { Heavy metals in } \\
\text { the fruits }\end{array}$ & $\mathrm{Cd}$ & $\mathrm{Ni}$ & $\mathrm{Pb}$ & $\mathrm{Zn}$ & $\begin{array}{c}\text { Moisture } \\
\text { content }\end{array}$ \\
\hline $\mathrm{Cd}$ & 1.0 & & & \\
$\mathrm{Ni}$ & 0.2016 & 1.0 & & & \\
$\mathrm{~Pb}$ & $0.5619 * *$ & 0.216 & 1.0 & & \\
$\mathrm{Zn}$ & 0.1801 & $0.4099 *$ & 0.1149 & 1.0 & \\
Moisture content & -0.3918 & 0.1232 & -0.5012 & 0.2581 & 1.0 \\
\hline
\end{tabular}

* Correlation is significant at the 0.05 level (2-tailed).

** Correlation is significant at the 0.01 level (2-tailed). 
Table 6. Correlation of heavy metals $(\mathrm{Cd}, \mathrm{Ni}, \mathrm{Pb}$ and $\mathrm{Zn})$ in the fruits and same metal in the soil:

\begin{tabular}{|ccccc|}
\hline $\begin{array}{c}\text { Heavy metals in } \\
\text { fruits }\end{array}$ & Cd & \multicolumn{3}{c|}{ Heavy metals in soil } \\
& & $\mathrm{Ni}$ & $\mathrm{Pb}$ & $\mathrm{Zn}$ \\
\hline $\mathrm{Cd}$ & $\mathbf{0 . 4 1 8}$ & & & \\
$\mathrm{Ni}$ & & $0.968^{* *}$ & & \\
$\mathrm{~Pb}$ & & $0.8913^{* *}$ & \\
$\mathrm{Zn}$ & & & $0.7314^{*}$ \\
\hline
\end{tabular}

* Correlation is significant at the 0.05 level (2-tailed).

** Correlation is significant at the 0.01 level (2-tailed).

Table 7. Correlation of heavy metals $(\mathrm{Cd}, \mathrm{Ni}, \mathrm{Pb}$ and $\mathrm{Zn})$ in the fruits and same metal in the groundwater:

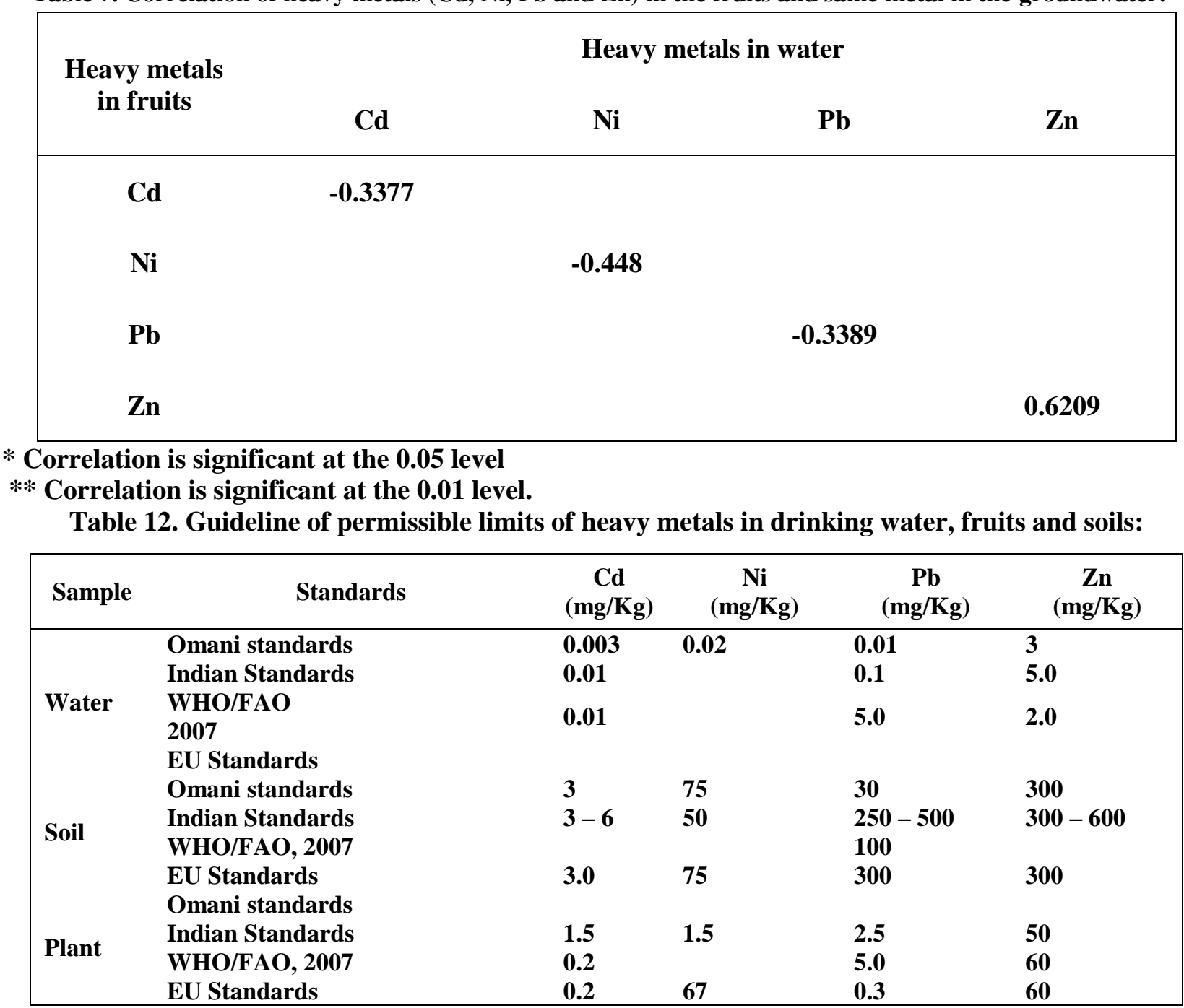

Sources:

1- Ministry of Commerce and Industry, Directorate General for Specifications and Measurements (DGSM). 


\section{REFERENCES}

1. Abass MA,ZK. Hassan and KM. Al-Jabary ..2015. Assessment of heavy metals pollution in soil and date palm (Phoenix dactylifera L.) leaves sampled from Basra/Iraq governorate. Advances in Environmental Sciences - Int J of the Biof Soc., 7(1).

2. Abbas and Hassan .2018. Evaluation of groundwater quality using water quality index (WQI) and GIS techniques. Iraqi Journal of Agricultural Sciences -1028:49(2):313- 326.

3. Abd-Elfattah A, SM. Shehata and AS Talab .2002. Evaluation of irrigation with either raw municipal sewage river water on element uptake and yield of lettuce and potato plants. Egy J. of Soi Sci, 42(4), 705-714.

4. Achary MS, KK. Satpathy, S. Panigrahi , AK. Mohanty, RK. Padhi , S. Biswas and RC. Panigrahy RC .2016. Concentration of heavy metals in the food chain components of the nearshore coastal waters of Kalpakkam, south east coast of India. Elsevier Ltd, Volume 72, Part B, pp. 232-243. doi: 10.1016/j.foodcont.2016.04.028.

5. Akinola, MO.,KL. Njoku and NV. Ifitezue .2011. Assessment of heavy metals (lead and cadmium) concentration in Paspalum orbiculare near municipal refuse dumpsites in Lagos state, Nigeria; $J$ of Ecol and the Nat Envi Vol. 3(16), 509 - 514.

6. Al-busaidi A., B. Shahroona , R. Alyahyai and M. Ahmed .2015. Heavy metal concentrations in soils and date palms irrigated by groundwater and treated wastewater. Pak $\mathbf{J}$ Agri Sci, 52(1), 129-134 .

7. Aldjain IM, MH. Al-Whaibi, SS.AlShowiman and MH. Siddiqui .2011. Determination of heavy metals in the fruit of date palm growing at different locations of Riyadh. Sau J of Bio Sci, 18(2), 175-180. doi: 10.1016/j.sjbs.2010.12.001.

8. Al-Harthi SS, A. Mavazhe , H. Al-Mahroqi and SA. Khan .2015. Quantification of phenolic compounds, evaluation of physicochemical properties and antioxidant activity of four date (Phoenix dactylifera L.) varieties of Oman. J of T Univ Med Sci, 10(3), pp.346-352.

doi:10.1016/j.jtumed.2014.12.006.

9. Al-Marshudi AS. .2007. The Falaj irrigation system and water allocation markets in
Northern Oman. Agric Water Mgt, 91(1-3), 71-77.

10. Al-Musharafi SK, IY. Mahmoud and SN. Al-Bahry .2012. Heavy metal contamination from treated sewage effluents. Water Pol XI. doi:10.2495/wp120331 .

11. Al-Musharafi SK, IY. Mahmoud and SN. Al-Bahry .2014. environmental hazards and pollution from liquid waste lagoons. IACSIT Press, 69 (1), pp. 1-5. doi: 10.7763/IPCBEE.

12. Al-Rashdi TT and H. Sulaiman .2013. Bioconcentration of heavy metals in alfalfa (Medicago sativa) from farm soils around sohar industrial area in Oman. APCBEE Procedia, 5, 271-278. doi: 10.1016/j.apcbee.2013.05.047.

13. Al-Sahaf, F.H , Y. M. Abed, F. F. Saleh and H. S. M. Khierallah .2017. Influence of spraying by some plant growth regulators on date palm salt tolerance enhancement. The Iraqi Journal of Agricultural Sciences - 48(1): 236-241,2017.

14. Al-Shayeb SM .2002. Lead and other elements in date palm (Phoenix datylifera $L$.) fruits (Dates). Asi J of Chem, 14(2), 577-582. 15. Al-Yahyai R. and M. Khan .2015. Date Palm Status and Perspective in Oman. Springer Science Business Media Dordrecht, 2, 207-240. doi:10.1007/978-94-017-9707$8 \_6$.

16. Baawain MS, A. Al-Omairi and BS. Choudri .2014. Characterization of domestic wastewater treatment in Oman from three different regions and current implications of treated effluents. Environmental Monitoring and Assessment, 186(5), 2701-2716. doi: 10.1007/s 10661-013-3572-x

17. Carter CJ and RA. Blizard .2016. Autism genes are selectively targeted by environmental pollutants including pesticides, heavy metals, bisphenol $\mathrm{A}$, phthalates and many others in food, cosmetics or household products. Neuro Int. doi10. 1016/j. neuint.2016.10.011.

18. Chojnacka K, A. Chojnacki , H. Górecka and H Górecki .2005. Bioavailability of heavy metals from polluted soils to plants. Sci of the Total Envt, 337(1-3), 175-182. doi: 10.1016/j.scitotenv.2004.06.009.

19. Chowdhury S, MAJ. Mazumder, O. AlAttas and T. Husain .2016. Heavy metals in drinking water: Occurrences, implications, and 
future needs in developing countries. Sci of The Tot Envt, 569, 476-488. doi: 10.1016/j.scitotenv.2016.06.166.

20. Dargin J.2013. Development and industrialization in the Arabian Gulf region. Harv J of Mid East Pol and Policy, 1-21.

21. Deribachew B, M. Amde , R. NigussieDechassa and AM. Taddesse .2015. Selected heavy metals in some vegetables produced through wastewater irrigation and their toxicological implications in Eastern Ethiopia. Afr J of F, Agric, Nutr and Dev, 15, 3rd ser., 10013-10032.

22. Hamid MA.2011. Growth and heavy metals uptake by date palm grown in monoand dual culture in heavy metals contaminated soil. Wor Appl Sci J, 15(3), 429-435.

23. Jung MC .2008. Heavy metal concentrations in soils and factors affecting metal uptake by plants in the vicinity of a Korean $\mathrm{Cu}-\mathrm{W}$ mine. Sensors, 8(4), 2413-2423. doi:10.3390/s8042413.

24. Khan S.,O. Cao, YM. Zheng, YZ. Huang and YG. Zhu .2008. Health risks of heavy metals in contaminated soils and food crops irrigated with wastewater in Beijing, China. Environ. Pollution. 152, 686-69.

25. Khayatzadeh J. and E. Abbasi .2010. The Effects of heavy metals on aquatic animals. The 1st International Applied Geological Congress, Department of Geology, Islamic Azad University -Mashad Branch, Iran, 688694.

26. Kilbride C. 2006. Application of sewage sludge and composts. Forest Research, 1-6.

27. Kumar SS, S. Ajay , B. Sunisha, S. Preeti and, Deepali .2003. Impact assessment of a cement industry on some environmental descriptors, M. Sc. Dissertation, School of Environmental Biology, APS University Rewa, India.

28. Mandal A, and M. Voutchkov .2011. Heavy Metals in Soils around the cement factory in Rockfort, Kingston, Jamaica. Int $\mathbf{J}$ of Geosci. 02(01), 48-54. doi:10.4236/ijg.2011.21005.

29. McLaughlin MJ, BA. Zarcinas, DP. Stevens and N. Cook .2000a. Soil testing for heavy metals. Commun. Soil Sci. Plant Anal., 31: 1661-1700. doi: $\underline{10.1080 / 00103620009370531 .}$.
30. McLaughlin, MJ,RE. Hamon , RG. McLaren, TW. Speir and SL. Rogers .2000b. Review: A bioavailability-based rationale for controlling metal and metalloid contamination of agricultural land in Australia and New Zealand. Australian J. Soil Res.,38: 10371086. DOI: 10.1071/SR99128 .

31. Mendoza-Carranza M, A. SepúlvedaLozada , C. Dias-Ferreira and V. Geissen .2016. Distribution and bioconcentration of heavy metals in a tropical aquatic food web: A case study of a tropical estuarine lagoon in SE Mexico. Env Pollution, 210, 155-165. doi: 10.1016/j.envpol.2015.12.014.

32. Ministry of Commerce and Industry, Directorate General for Specifications and Measurements (DGSM), 2012 Omani Standard No. 8/2006 "Un- Bottled Drinking Water".

33. Ministry of Environment and Climate Affairs .2013. Omani environmental regulations international references documents SEU Guidance Notes, 2nd edition, ARWA.

34. Naser HA. 2013. Assessment and management of heavy metal pollution in the marine environment of the Arabian Gulf: A review. Marine Pollution Bulletin, 72(1), 613. doi: 10.1016/j.marpolbul.2013.04.030.

35. Patel AH .2015. Electrical Conductivity as Soil Quality Indicator of Different Agricultural Sites of Kheda District in Gujarat. Int J of Inn Res in Sci, Eng and Tech, 4(8), 7305-7310. doi:10.15680/IJIRSET.2015.0408111.

36. Rai M and G. Kövics .2010. Progress in mycology. Jodhpur, India: Scientific Publisher, P 372.

37. Sakadevan K. and M. Nguyen .2010. Extent, impact, and response to soil and water salinity in arid and semi-arid regions. Advances in Agronomy 109: 55-74. doi: 10.1016/S0065-2113(10)09002-4 .

38. Shafiq M, IM Zafar and M. Athar .2008. Effect of lead and cadmium on germination and seedling growth of Leucaena leucocephala. J of Appl Sci and Env Mgt, 12(3), 61-66. doi: 10.4314/jasem.v12i3.55497. 39. Shahin MM. and MR. Alhajhoj .2015. Effect of different irrigation water qualities on the content of some macro and micronutrients in leaves fruit, as well as yield and fruit quality of some date palm cultivars in Al-Hassa Oasis. 
Middle East Journal of Agriculture Research, 834-847.

40. Solgi E. and H. Khodabandelo .2016. Cadmium and lead disruption in soils around the Hegmatan cement factory, Iran. Health Scope, In Press (In Press), 1-7. doi: 10.3390/ijerph9093209.

41. Stephen de Mora,,SS. Fowler SS, E. Wyse and S. Azemard .2004. Distribution of heavy metals in marine bivalves, fish and coastal sediments in the Gulf and Gulf of Oman. Mar Poll Bull, 410-424. doi: 10.1016/j.marpolbul.2004.02.029.-

42. Sudharmaidevi CR, KCM. Thampatti and N. Saifudeen .2017. Rapid production of organic fertilizer from degradable waste by thermochemical processing. Int $\mathbf{J}$ of Recycling of Organic Waste in Agric, 6. https://doi.org/10.1007/s40093-016-0147-1.
43-Tabatabaei SH, R. Fatahi Nafchi, P. Najafi , MM. Karizan Z. Nazem .2017. Comparison of traditional and modern deficit irrigation techniques in corn cultivation using treated municipal wastewater. Int $J$ of Recycling of Organic Waste in Agric, 6(1), 47-55. https://doi.org/10.1007/s40093-016-0151-5. 44-Williams JR, and AE. Pillay .2011. Metals, metalloids and toxicity in date palms: potential environmental impact. J of Env Protection 02(05), 592-600. doi:10.4236/jep.2011.25068. 45-Yan X, F. Zhang, C.Zeng, M. Zhang, LP. Devkota and T. Yao .2012. Relationship between heavy metal concentrations in soils and grasses of roadside farmland in Nepal. Int J of Env Research and Public Health, 9(9), 3209-3226. doi: 10.3390/ijerph9093209 